E International

The Regulatory Asset Base Model and the Project Finance Model: A comparative analysis

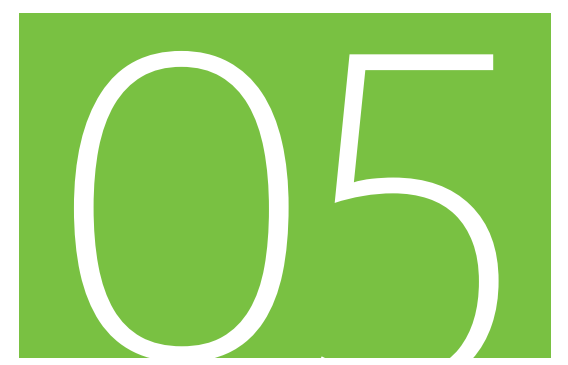

Discussion Paper 2015•05

Dejan Makovšek

International Transport Forum, Paris, France 


\title{
The Regulatory Asset Base Model and the Project Finance Model: A comparative analysis
}

\author{
Discussion Paper 2015-5
}

\author{
Dejan Makovšek ${ }^{1}$ \\ International Transport Forum \\ Paris \\ France
}

February 2015

The author is an Economist at the International Transport Forum at the OECD. The views and opinions expressed in this paper are his own and not necessarily aligned with the views of the organisation he is affiliated with. Comments on an earlier version by Darryl Murphy, Frederic Blanc-Brude, Daniel Loschachof, J.L. Guasch and Marian Moszoro are gratefully appreciated. 


\section{THE INTERNATIONAL TRANSPORT FORUM}

The International Transport Forum at the OECD is an intergovernmental organisation with 54 member countries. It acts as a strategic think-tank, with the objective of helping shape the transport policy agenda on a global level and ensuring that it contributes to economic growth, environmental protection, social inclusion and the preservation of human life and well-being. The International Transport Forum organises an annual summit of Ministers along with leading representatives from industry, civil society and academia.

The International Transport Forum was created under a Declaration issued by the Council of Ministers of the ECMT (European Conference of Ministers of Transport) at its Ministerial Session in May 2006 under the legal authority of the Protocol of the ECMT, signed in Brussels on 17 October 1953, and legal instruments of the OECD.

The Members of the Forum are: Albania, Armenia, Australia, Austria, Azerbaijan, Belarus, Belgium, Bosnia and Herzegovina, Bulgaria, Canada, Chile, People's Republic of China, Croatia, Czech Republic, Denmark, Estonia, Finland, France, Former Yugoslav Republic of Macedonia, Georgia, Germany, Greece, Hungary, Iceland, India, Ireland, Italy, Japan, Korea, Latvia, Liechtenstein, Lithuania, Luxembourg, Malta, Mexico, Republic of Moldova, Montenegro, the Netherlands, New Zealand, Norway, Poland, Portugal, Romania, Russian Federation, Serbia, Slovak Republic, Slovenia, Spain, Sweden, Switzerland, Turkey, Ukraine, United Kingdom and United States.

The International Transport Forum's Research Centre gathers statistics and conducts co-operative research programmes addressing all modes of transport. Its findings are widely disseminated and support policymaking in Member countries as well as contributing to the annual summit.

\section{Discussion Papers}

The International Transport Forum's Discussion Paper Series makes economic research, commissioned or carried out at its Research Centre, available to researchers and practitioners. The aim is to contribute to the understanding of the transport sector and to provide inputs to transport policy design.

ITF Discussion Papers should not be reported as representing the official views of the ITF or of its member countries. The opinions expressed and arguments employed are those of the authors.

Discussion Papers describe preliminary results or research in progress by the author(s) and are published to stimulate discussion on a broad range of issues on which the ITF works. Comments on Discussion Papers are welcomed, and may be sent to: International Transport Forum/OECD, 2 rue André-Pascal, 75775 Paris Cedex 16, France.

For further information on the Discussion Papers and other JTRC activities, please email: itf.contact@oecd.org

The Discussion Papers can be downloaded from: www.internationaltransportforum.org/jtrc/DiscussionPapers/jtrcpapers.html

The International Transport Forum's website is at: www.internationaltransportforum.org

This document and any map included herein are without prejudice to the status of or sovereignty over any territory, to the delimitation of international frontiers and boundaries and to the name of any territory, city or area. 


\begin{abstract}
The traditional approach to public infrastructure delivery and management has been challenged in the past decades through different forms of private capital participation. Two well established platforms for private capital participation in the context of public infrastructure procurement are the Regulatory Asset Base (RAB) Model and the Project Finance Model (broadly termed as PPP - Public-Private Partnerships). Based on a literature review, this paper assesses the two vehicles in terms of efficiency in delivery and operation of major infrastructure. Overall the basic concern with regard to RAB is that the approach might lead to excessive capital expenditures, thus slowly increasing the base on which the return is being calculated. Conversely, in the case of the PPP, given the complexity of the projects and the long-period of contractual commitment and uncertainty, it is questionable whether competition could lead to efficient outcomes. Put differently, in the case of the PPP, the basic concern is the required returns, and not the base. Available evidence seems to suggest, that the concern relating to the PPP returns is of a much greater magnitude than the perceived capex bias in the case of the RAB model, given that the latter is not easily detectable. Contrarily to a PPP, RAB is also sufficiently flexible to better accommodate changes in the environment in policy over time, without defeating the economic purpose of the model. Lastly, PPPs are known for their superior performance in in terms of on time and on budget infrastructure delivery. It may be possible to import some of the incentives in infrastructure delivery from the PPPs to a RAB model, but it is not clear, whether the same performance could be achieved with simpler performance construction contract approaches.
\end{abstract}




\section{Table of Contents}

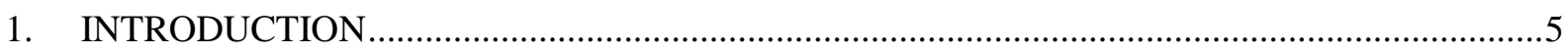

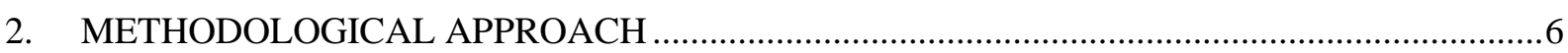

3. THE TRADITIONAL MODEL - THE BASELINE SCENARIO ….............................................

3.1 Infrastructure delivery - the traditional approach...................................................................

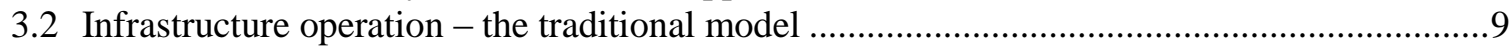

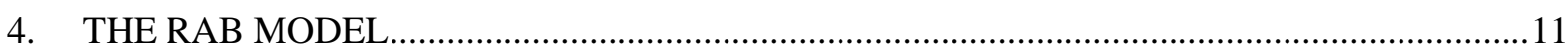

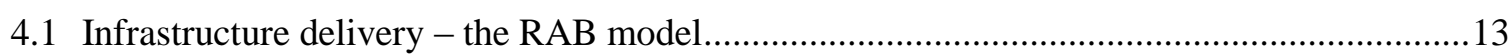

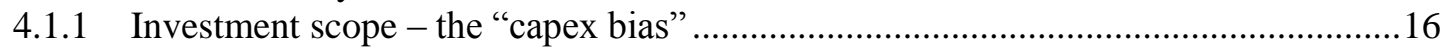

4.1.2 The higher gearing bias and inadequate returns ..................................................16

4.2 Infrastructure operation - the RAB model in an incentive regulation framework .................17

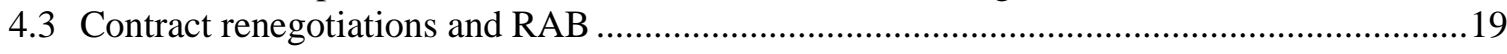

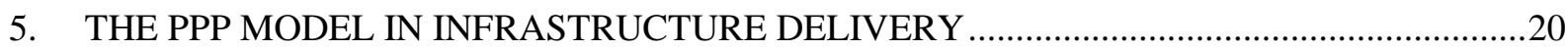

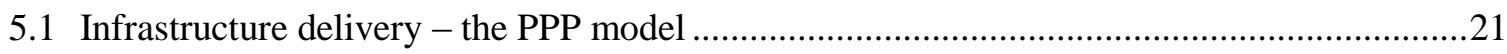

5.1.1 Potential for optimisation and redundancy in the delivery model .............................22

5.1.2 Ex-ante risk, ex-post risk and returns in a PPP....................................................23

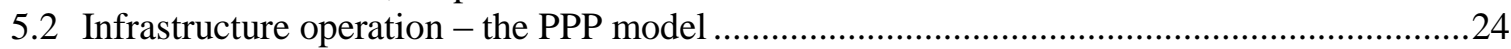

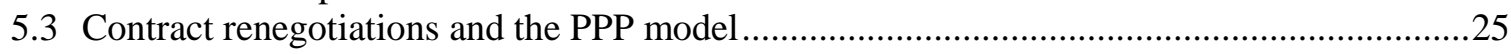

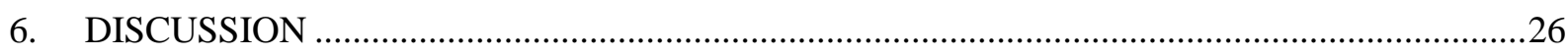

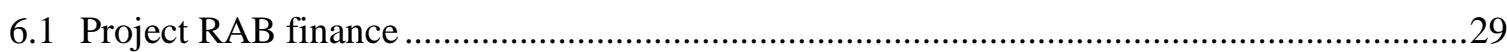

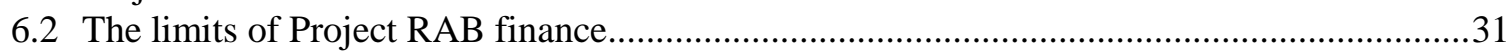

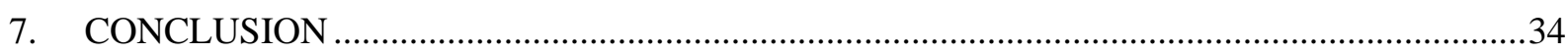




\section{Introduction}

Investment in infrastructure is important for productivity and growth, for future generations as well as today. A recent study by McKinsey (Dobbs et al. 2013) compiled multiple sources of information on the so called "infrastructure gap", estimating the needs to some USD 57 trillion over the next 30 years. Almost half of this amount pertains to the transport sector. Even if adjusted for potential bias, this kind of exercise is prone to, the demand in clearly large. The immediately apparent solution to fill the gap is to try to seek out new sources of financing. The OECD - Organisation for Economic Development and Cooperation for example is currently engaged in a research project ${ }^{2}$, to explore instruments to facilitate greater involvement of institutional investors in infrastructure financing.

All countries lack a national balance sheet to accurately (in terms of current cost accounting) represent the condition of the infrastructure nationwide. Estimates are therefore possibly significantly inaccurate. Furthermore, initiatives which concern better use of existing infrastructure and other similar approaches may reduce the perceived need of such investment. But despite these issues, it is clear that any estimated number that concerns "infrastructure" will by the very nature of the sector be substantial. The social welfare outcomes of these investments will be critically dependant on the price we have to pay for their financing, delivery, and management.

Countries around the world have tried to address these challenges with the introduction of private capital, with UK considered to be the forefront. Two concepts have been the primary vehicles through which private capital was introduced into the delivery and management of infrastructure: the regulatory asset base model (RAB) and the project finance model.

In the RAB model, economic regulation aims to provide efficiency incentives to the infrastructure manager, which would behave much like a natural monopoly in the absence of these incentives. Efficiency incentives for the private company are derived from the "competition" with the regulator the purpose of economic regulation is to mimic the incentives, otherwise produced by the market. The efficiency gains in this case arise through the interaction between the regulator and the regulated company "during the contract".

The project finance model, termed as Public Private Partnerships (and Private Finance Initiative in the UK) in the context of public infrastructure delivery, involves a contract with a private consortium, commonly a DBFMO (Design-Build-Finance-Maintain-Operate) contract for a single infrastructure project. For purposes of clarity we apply the term PPP throughout this paper. The efficiency gains in this approach are determined in a single point in time (the bidding process) "ex-ante the contract", by competition between the bidders for the contract.

The advantage of RAB is that in developed economies it offers one of the lowest costs of financing right after the government bonds. At the same time in incentive regulation it can provide adjustable, high powered incentives for efficiency during the life of the infrastructure. The adjustments occur

2 http://www.oecd.org/pensions/private-pensions/institutionalinvestorsandlong-terminvestment.htm 
during price reviews, which are in fact a string of contract renegotiations, required over the long life of infrastructure. Economic regulation is not without challenges. Arguably one of the more significant ones is incentivizing efficient capital expenditures, which is a problem that appears to be more adequately solved in PPPs in terms of the level of necessary expenditure and the efficiency of delivery (but not necessarily the choice of the investment in first place).

PPP are well established for delivering projects on budget and on time, however, the cost of finance is substantially higher, while during the operations phase, the PPP contract is considered to be relatively rigid. Renegotiations are possible, but a comparable framework to incentive based regulation in RAB is not in place.

These two approaches could be considered as two diametrically opposite solutions to the same challenge of infrastructure financing, delivery and management. In between them, there are other alternatives, which take various forms, from management contracts to other types of concessions. These are closer to the first or the second discussed generic solution and are not discussed in this paper $^{3}$.

A natural question that arises is, if and how would it be sensible to merge the advantages of both approaches -- the low cost of finance, efficiency in infrastructure delivery and powerful incentives for efficiency during operations -- in a single model?

\section{Methodological Approach}

In the following chapters we review the available empirical literature and illustrate what problems the $\mathrm{RAB}$ and project finance approaches were designed to solve and what challenges remain unsolved. In our approach we focus on two dimensions of efficiency:

- Efficiency in infrastructure delivery;

- This dimension refers to the question of "how". It is the ability to deliver projects (capital expenditure) without excessive cost overruns and delays and at a quality and price ${ }^{4}$ which are optimal from a life cycle perspective.

- Efficiency in infrastructure operation;

- This dimension too refers to the ability to produce a given output with the minimum possible input (operational expenditure in this case).

3 Other approaches, such as management concessions without capital investment, either do not involve (private) money at risk or are variation of one of the two basic approaches presented.

$4 \quad$ We stress that there is a clear difference between the cost (price) of the project and the ability to deliver the project on budget. The first notion relates to the use of proper materials/technologies, which will during the life-cycle of the project lead to the lowest total cost at a given performance. The second notion refers to the ability to efficiently manage (and estimate) the risks in the delivery of the project. 
Across the two dimensions above, we compare the RAB and PPP against the traditional procurement and state-owned infrastructure management model as a baseline.

- The efficiency in terms of the allocation of investments - the question of "what" (i.e. the optimal volume and selection of investments), is not a subject of our analysis as PPPs and the RAB are not completely comparable in this context. A PPP can primarily be seen as an infrastructure procurement or delivery vehicle, where it has already ex-ante been decided, whether a project is desirable or not on the relevant policy level. For major projects, this will be the national policy level (i.e. it is the responsibility of the relevant ministry). For smaller projects, PPPs as a delivery vehicles are not appropriate, due to the transaction cost involved. If a RAB model would be used to deliver a major infrastructure project, the case would be the same. The distinction with the RAB model is, that on a smaller project scale, regulated industries do invest in the existing infrastructure and its expansion and are involved in the "how" and the "what" questions

- Based on the comparison of the two models, we then discuss, whether there is room to combine any elements of the two models, which would lead to an improved infrastructure delivery and management vehicle.

\section{The Traditional Model - The Baseline Scenario}

The term "traditional" denotes something that has remained more or less unchanged through time, an established method. Indeed the dominant method of major infrastructure procurement has remained unchanged for decades, while the processes and technologies for infrastructure planning and delivery have progressed. As noted in the introduction, we describe below the main characteristics related to the chosen two dimensions of analysis (delivery, operation).

\section{Infrastructure delivery - the traditional approach}

The traditional model is a contract structure, where the phases of design and construction are tendered separately or bundled. The DBB contract (Design-Bid-Build) conforms to the first description and the DB (Design\&Build) to the second. In the context of public infrastructure delivery, the term "traditional" also involves the financing with public funds or through government borrowing.

This method has several main characteristics that we treat below:

- In large projects traditional procurement involves the use of cost-plus contracts ${ }^{5}$, which has primarily three consequences for the public sector as the procuring authority:

$5 \quad$ In this paper we apply the term "cost-plus" contract as opposed to fixed price/fixed date of delivery contracts to mark the expected outcomes of both. In detailed treatment the cost plus-contract is one of several arrangements in traditional procurement, including for example a fixed unit price contract. 
- The public sector retains most of the risks.

- The public sector also retains the possibility of changing the scope of the project during construction with relatively little transaction cost. But since the infrastructure construction period usually lasts a few years, it is unlikely for the objective circumstances to change frequently so as to require changes in project scope. Accordingly, this possibility rather facilitates moral hazard, by making it easier for the public sponsor to conceal the true cost/benefits during the decision making stage (Flyvbjerg et al 2002 and related work are one of the key references in this area).

- The cost-plus contract enables the participation of a larger number of potential contractors during the bidding stage as it does not require the transfer of major risks. Accordingly the capital (and efficiency) requirements on the bidders are lower. On the other hand, it enables strategic behaviour, where the bidders conceal their true revenue expectations during the bidding stage (Liu et al. 2007), leading to pressures on the sponsor during the construction. Indeed there is a documented relationship (Williams et al. 1999; Jahren and Ashe 1990) between the magnitude of the low bid and measured cost overruns (against the winning bid).

- The planning, building, and the operation phases are commonly performed by three different entities. In such a setup each actor leaves the "scene" after his engagement is completed, hence limiting incentives to consider future consequences of decisions in each of the phases ${ }^{6}$. This makes the implementation of life cycle cost optimization principles difficult. But more importantly, the sponsor (the public entity), which should be the most interested actor in life cycle cost optimisation, is also subject to political short termism. Politicians have an incentive to cut the red ribbon for as many projects as possible, without considering future cost of this infrastructure. This leads to the construction of lower quality infrastructure without regard for future cost operation or even the wrong infrastructure that is possibly not even absolutely necessary.

There is now an increasing volume of literature available on the performance of the traditional infrastructure project delivery in terms of on budget and on time delivery and also on the realisation of expected benefits. One part of the literature (examples of more recent research includes Flyvbjerg 2002, 2003; Odeck 2004; Cantarelli 2012a; Cantarelli 2012b; Makovšek et al. 2012) measures performance against the decision to build estimate, which refers to the choice of investments. Measured cost overruns on average, when compared to the decision to build estimate reach from $8 \%$ to over $40 \%$ in the case of transport infrastructure. Another part of the literature focuses on contract performance (Blanc-Brude and Makovšek 2013 include a literature review). There, cost performance is measured against the contract price and systematic cost overruns for road infrastructure are on

With »cost-plus« we refer to contract types, which offer a weak guarantee "ceteris paribus" to the investor that the project will be delivered for the contracted value, including the design and build contract. The fixed price/fixed date of delivery contract involves a TLS (Total Lump Sum) contract, with a comparably strong guarantee to the investor, that the contract value will not be exceeded (provided of course, that the investor does not change the content of the project).

In traditional procurement the Design and Build procurement resolves part of the problem with regard to incentives, but it would still be inferior to a contract, which also bundles the operations phase. 
average below 9\%. For other infrastructure types (power generation and distribution, water supply and distribution...), the evidence is more scarce although similar outcomes can be expected ${ }^{7}$.

\section{Infrastructure operation - the traditional model}

Once the infrastructure is delivered, again in terms of the traditional context, its management and operation is transferred to a state-owned infrastructure manager. The challenges typically faced in the management phase or characteristics included:

\section{- Performance incentives}

- Infrastructure management companies share several characteristics with natural monopolies (entry barriers in terms of sunk cost, economies of scale and scope etc.); accordingly, they are not subject to adequate competitive pressures. We address the evidence on the comparative performance of regulated and privatized infrastructure managers in the next chapter (The RAB model).

- In relation with the point above, within large monopolies with considerable market power, unions organize more easily (Salinger 1984, Rose 1987, Hendricks 1977) and can exert considerable power on the company and its owner. In addition, Savedoff and Spiller (1999) explain how the threat of governmental opportunism leads publicly owned companies to pursue strategies for the protection of their cash flows against such hazards by undertaking actions, which translate into low efficiency and quality levels (e.g. hiring too many employees, granting excessive benefits).

- $\quad$ Cost recovery and life-cycle optimisation

- Cost recovery with regard to existing infrastructure is subject to government shorttermism. The risk of government's short-termism stems from voter's expectations, who appreciate the lowest possible price, which does not immediately affect the quality of the service they receive, with little concern for the consequences for the distant future generation. Helm (2009) refers to this challenge as the time inconsistency problem.

- When infrastructure managers are state-owned companies, they will continue to operate as long as the marginal cost is covered or as long as workers get paid. The "savings" are manifested in a slowly deteriorating condition of the infrastructure. Persistent lack of renewals can eventually lead to excess current maintenance requirements (a graveyard spiral), which entail even higher manpower or expenditure requirements than before. Moreover the burden of the deferred costs of replacement or maintenance investment is now transferred to the next generation of taxpayers or users. The optimisation of the infrastructure lifecycle cost becomes impossible.

- The approach to infrastructure development and maintenance as described above also causes unexpected replacement costs and makes future expenditure planning and thus optimization in that sense also difficult.

$7 \quad$ A recent study on cost overruns in the case of dams (Ansar et al 2014) estimated the systematic cost overruns measured against the decision to build for mainly developing countries at $104 \%$, while the same measure for North America was estimated at $11 \%$. 
To summarize over the two dimensions, the main challenge in infrastructure delivery and management is the creation of efficiency incentives in delivery and operation, but without a consistent funding structure, which makes full cost recovery possible, optimal operational efficiency is not possible.

In economics it has long been theoretically expected but only recently empirically established, that the performance of the private ownership in a competitive market is superior to public ownership (Meginson and Netter 2001). Although the characteristics of network industries are different from firms on the competitive markets, countries have aimed to repeat the result also in this area. However, because the characteristics (sunk cost, long life, externalities ${ }^{8}$ ) of many network systems would inherently lead to multiple market failures, if simply left to the devices of the private sector, some form of government intervention remains necessary. In fact as Helm $(2009,321)$ notes, the role of the state is crucial, because it is ultimately the state, which decides on the overarching objectives of (national) CAPEX programmes i.e. it is the state that takes the responsibility for investment allocation.

Participation of private capital in infrastructure delivery and management in such circumstances is not possible in the long run. To make it possible, a credible commitment by the government is necessary. Because investments in large physical infrastructure are sunk, it is unlikely that private investors would commit to investments where there is explicit or implicit (e.g. through pricing decisions) risk of expropriation, as outlined in this chapter.

The next two chapters present two approaches, that have evolved to solve this problem - the RAB in the framework of incentive based regulation and PPP. A brief description of each approach is followed by the analysis across the same two dimensions as above.

$8 \quad$ For example transport infrastructure is inherently related to positive (such as better accessibility or agglomeration benefits) and negative externalities (e.g. noise, pollution). It is impossible for the investor to directly capture positive externalities and to monetize them and he will not voluntarily be held liable for the negative externalities. Both are however in the interest of the wider society. 


\section{The RAB model}

The type of economic regulation employed is normally subject to the context in which it has to be used.

In general, regulation in capex intensive network industries (e.g. railways, electricity transmission, water supply and treatment) is subject to ex-ante price controls, which is the strongest form of economic regulation ${ }^{9}$ as it already assumes some form of market failure exists. Capital-intensive network industries are or have some of the characteristics of natural monopolies, which imply that the development of competition is not possible.

There are mainly three types of ex ante price controls - price caps, revenue caps and rate of return regulation. With the price and revenue caps, the regulator must estimate the efficient cost of providing a service for the next regulatory period (price review period) and allow the regulated company to recover that cost, if it met the efficiency target.

There are two main approaches towards the calculation of this efficient cost of service provision, i.e. the required revenue for the regulated company. One is the building block approach, and the other is a forward looking approach (e.g. LRIC-Long Run Incremental Cost, commonly applied in telecommunications).

RAB corresponds to the building block approach. According to Stern (2013) the RAB concept emerged in UK to provide assurance to investors in privatised network utilities. RABs were developed in the 1990s by the economic regulators for the purpose of setting price caps. The concept refers to the assets used in the performance of a regulated function. In practice it is an accounting number - it reflects the value of past investments into infrastructure.

Historically, thus the RAB model was developed as a part of the privatisation process in the UK and was applied to existing assets. It was not envisaged to be used in the delivery of major Greenfield stand alone investments.

The regulator must ensure that the $\mathrm{RAB}$ is maintained in line with the financial capital maintenance principles (and current cost accounting where sensible). Financial capital maintenance ${ }^{10}$ requires that the monetary or market value assets be preserved through time (takes into account price growth through time); while current cost accounting ensures that a proper replacement value is taken into account. Because infrastructure is long-lived, the initial procurement value of assets years or decades

$9 \quad$ Other "lighter" forms of economic regulation involve pricing rules (preventing the dominant operator from abusing its market power, as for example in telecommunications or postal services) or an application of transitory measures (e.g. non-discrimination clauses, price monitoring), where the market is deemed competitive, but one operator still has significant market power.

10 The alternative to this concept is the physical capital maintenance, focused on maintaining the productive capacity of assets, i.e. on a company's ability to generate a certain amount of products/services. 
ago does not necessary reflect their current replacement value, thus the proper depreciation must be sufficient to buy the modern equivalent asset. Both concepts prevent hidden expropriation.

In addition to maintaining the value of $\mathrm{RAB}$ and allowing its expansion, the regulator must also secure the financing of other cost. The generated revenue should thus enable the regulated company to secure:

- Depreciation (investments to preserve the value of the RAB);

- New investments into new infrastructure (investments, which increase the RAB);

- Operating costs;

- Financing cost (the cost of equity and debt, which involve and an appropriate reward or return).

The return to investors is based on the value of RAB (the value of "investment" on, which the return is made) and WACC (the rate of return), while the operating costs are remunerated on a pay-as-you-go basis.

An example of the model is presented in the figure below.

Figure 1. An illustration of the RAB model

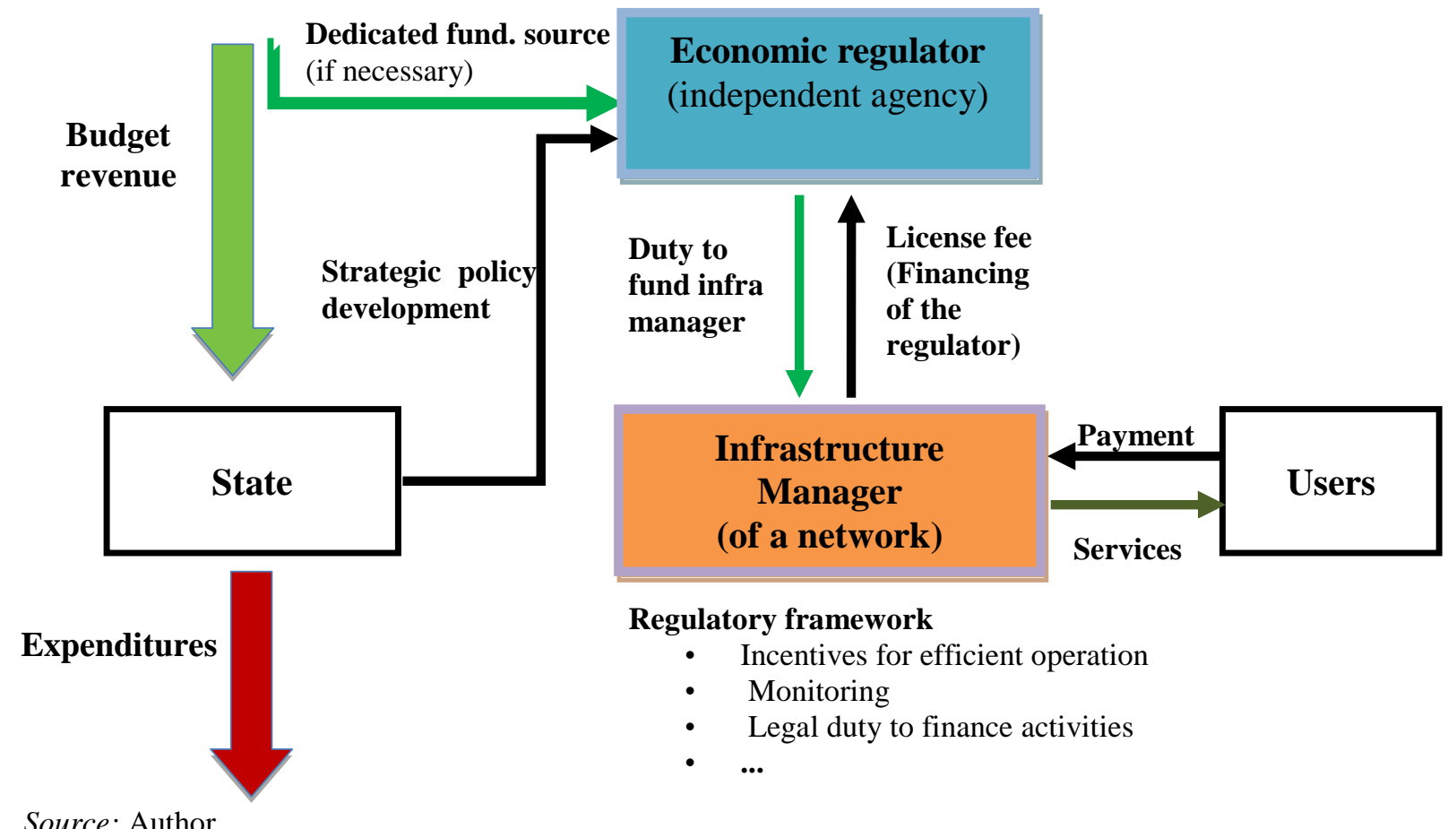

The RAB is a generic concept and can be embedded in different regulatory frameworks, with more or less powerful incentive regimes. The incentive regimes are the subject of a vast theoretical and empirical literature, that has accumulated over the past decades, with generic as well as sector specific contributions (industry specifics for different regulated sectors bring about different challenges and required solutions). Joskow (2008) provides a good overview of the general theory behind incentive regulation. 
Apart from theoretical advances in incentive regulation, different regulatory traditions in different geographical locations (e.g. in Australia, continental Europe, UK, US) have introduced nuances in the practice of regulation.

In terms of legal execution the RAB model involves the granting of a license (which specifies the rights and obligations) and in that framework the relevant infrastructure company and its assets can in principle be privatized or remain in public ownership.

It is acknowledged, that some of the elements of the RAB model are subject to criticism. The main criticisms include the potential bias to a higher gearing and the potential capex bias, which are addressed in the next subsection. In both cases it is not yet fully clear, whether the issues are material, i.e. whether they can be properly resolved by the regulator.

We present below the implications of this approach over the two dimensions of analysis, described initially, against the base case of the traditional model.

\section{Infrastructure delivery - the RAB model}

Ex-ante price controls based on a building block approach generally allow all capital costs incurred to be recovered through the price control (Frontier Economics 2010). But the regulators, based on benchmarking, engineering analysis or other approaches can and do employ targets for efficient CAPEX spending (on the budget/programme level), where the regulated company can keep the reward for meeting/undershooting the investment target at a given level of output or is penalized for missing the target at the end of the regulatory period ${ }^{11}$. To address the question of efficient capex delivery, regulators have at their disposal a number of tools, from benchmarking analysis, historical trends, to cost modelling techniques, among others. Full scrutiny of the capex spending (e.g. detailed engineering audit on most projects) is generally not sensible, due to the regulatory burden, such form of monitoring would imply, but regulators do try to observe asset quality measures.

The procurement of new (or renewal/upgrade of existing) infrastructure in the context of regulated network industries is normally subject to the general competition legislation and in practice may employ traditional procurement models (the Design-Bid-Build contracts) or more advanced approaches, involving performance contracting, alliancing and others. We have not encountered a good current overview of the incidence of different procurement practices or approaches of regulated companies in network industries, but NERA (2004) reports most utility companies in the past in the UK relied on subcontracting and/or in-house provision.

As noted above, the regulators reserve the right to include only the "efficient" part of these investments into the RAB but it is hard to imagine how they can determine, for example, what part of the possible cost overruns, measured against the contract price or compared to earlier estimates, was efficient or justified. Costs for similar projects can vary substantially. To illustrate, Bain (2010) notes that for the road sector notes, that outturn costs for resurfacing a dual 3-lane motorway by the British

$11 \quad$ Menus of options may be applied. For example the regulated company may choose between a higher capex allowance with lower retention rate and a lower capex allowances with higher retention rates. In effect, companies, that believe they will have higher capex requirements that the regulator forecasted, can choose a higher capex allowance, but the penalty for overspending above the allowance - i.e. overshooting the target will be higher. 
Highway Agency were reported to vary from $£ 0.24$ million to $£ 0.70$ million per $\mathrm{km}$. Thus, while the instruments mentioned above are helpful, they are nevertheless "inaccurate" and cannot completely address the information asymmetry between the regulator and the regulated company.

In an incentive based regulation, the investment plans and the required revenue to finance those investments are a matter of "negotiations" or an iterative game between the regulated company's idea and the regulators perception of the actual needs. Due to information asymmetries and examples, such as the one above, it is very difficult for the regulator to establish a relatively precise amount of investment needed to match certain output targets. Moreover, in terms of delivery performance of individual projects, judgements of the regulator on for example what part of cost overruns is warranted and what part not, might be perceived as a disincentive to investment from the private owners. It is therefore not surprising, if a strong safety margin (in the past a pass-through model was in place in the UK; NERA 2004) would be in place in the regulator's efficiency targets. Incentives for good project performance in such a structure are inaccurate, and a part of the inefficiency in infrastructure delivery will be passed on to the RAB.

While there is no available evidence published directly on the "safety margin" in infrastructure delivery performance, there is evidence available for the example of the required rate of return (on the $\mathrm{RAB}$ ) to illustrate the analogy. The required rate of return for the private investor is determined based on the WACC, which is initially a range estimate. Regulators (in a number of sectors in the UK and Australia) choose to err on the upside and apply WACC values substantially above the midpoint estimate of the range. The regulators (a review of the regulatory practice in different sectors in the UK and Australia is provided in Frontier Economics 2014) acknowledge their inability to accurately estimate this parameter, but note that the social welfare cost of underestimation of this parameter is greater than the overestimation (in line with Dobbs 2011), as the former could lead to a lack of investments ${ }^{12}$.

In terms of infrastructure investment delivery performance in regulated industries, there is almost no data publicly available. Despite the fact, that there cannot be any business confidentiality considerations and public money is implicitly involved, this is in sharp contrast with traditional public procurement, where an increasing volume of research is becoming available ${ }^{13}$. A rare example for the regulated sector is the study of Sovacool et al. (2014), which provide some data for the electricity transmission sector in terms of on time and on budget delivery. The on budget delivery is presented in the figure below.

12 The Frontier Economics (2014) study also cites multiple examples, to provide some idea about the range in question: In the case of Bristol Water determination, a WACC range of $3.8 \%$ to $5.0 \%$, and adopted a point estimate was $5.0 \%$, which is the 100th percentile of the range; for water networks in England and Wales, a WACC was estimated in the range of $2.9 \%$ to $5.4 \%$, and a point estimate of $4.3 \%$ was adopted; in the Stansted Airport determination, a WACC range of $5.20 \%$ to $7.54 \%$ and adopted a point estimate of $7.10 \%$, which is the 81 st percentile of the range. 
Figure 2. Cost overruns in electricity transmission projects in the USA in Sovacool et al. (2014)

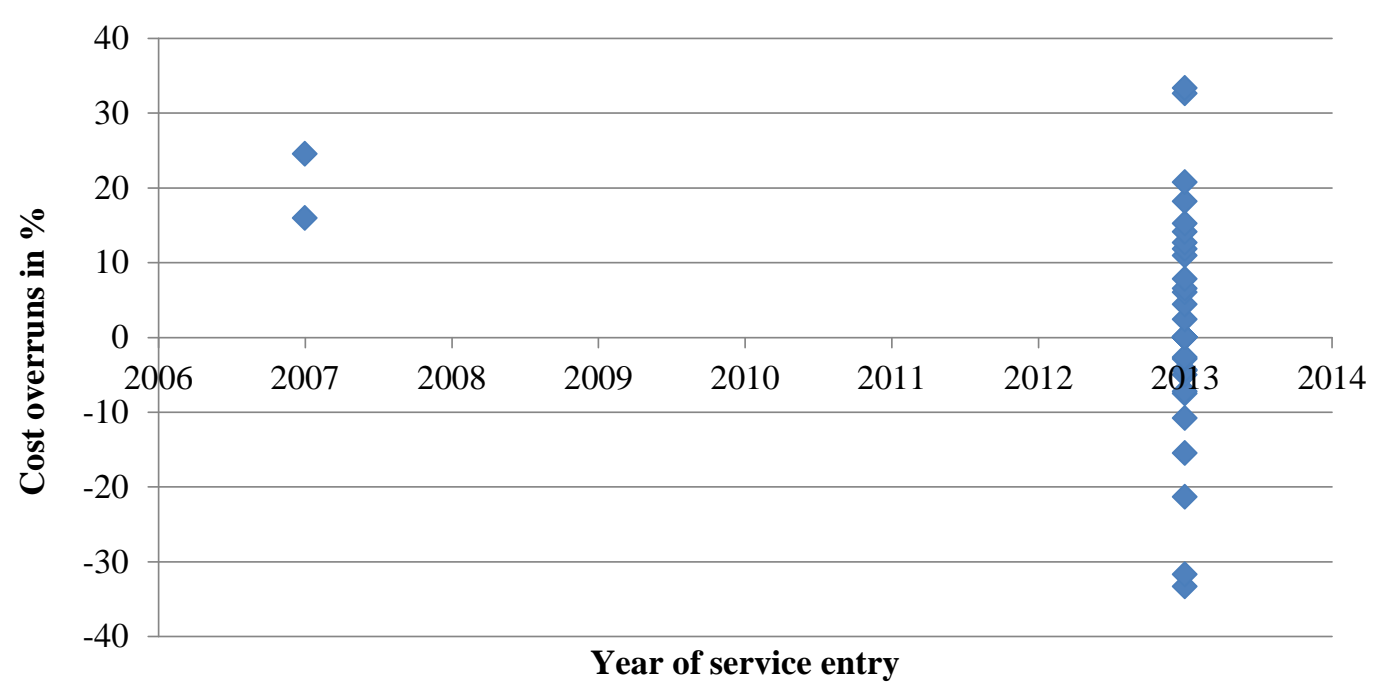

$\bullet$ Cost overruns in electricity transmission projects

Source: Sovacool et al., 2014.

As the electricity transmission sector in the US is regulated as well, it implicitly provides some measure of the ability to build to the budget in the electricity transmission sector. Performance in terms of construction to the budget is very good, when compared to studies, which dealt with traditional procurement, albeit for the transport sector. For the Sovacool et al. (2014) ${ }^{14}$ data we could infer an average systematic cost overrun of $2.2 \%$ or a total impact of USD $162 \mathrm{~m}$, against the estimated spend of USD 4.174 million, and a cost overrun reported on 40 of the projects for a sample of 40 projects from the US. In the transport sector and traditional procurement the average cost overrun is recorded in the range from $8 \%$ to over $40 \%$, depending on the transport infrastructure in question (Blanc-Brude \& Makovsek 2013). If the portfolio of projects in this sample was executed by a single company, at least in terms of on budget delivery, its performance could be deemed as very good. If, however, total cost overruns were higher, a part of them would become a part of the RAB, i.e. part of the construction risk would be passed to the consumers.

In terms of strategic behaviour of the regulated company one point may be added. In the above distribution $40 \%$ of the projects had a cost overrun and $30 \%$ of the projects had a cost underrun. If the penalty for missing the capex target would be very strong and the regulated company would incur a significant cost overrun on some projects, it could attempt to reduce spending on the others, in spite of possible life cycle costing inefficiencies in the future.

The above argumentation focused mainly on the cost of infrastructure, but with regard to its quality, it is important to note a difference, with the incentives in the traditional model. In the RAB model, when an incentive based regulation is in place, the regulated company has to observe the effect of the quality of infrastructure on future cost of operation. By preferring to build cheap infrastructure without

14 We note that the data set involves measuring a cost overrun against the budget as opposed to measuring against the procurement contract, does not immediately imply a negative nature of the cost overrun. In terms of construction risk, what is more relevant is the cost overrun, measured against the winning bid, which is a strongly related but different measure. 
concern for future cost of operations, it would penalize itself ${ }^{15}$. Thus, the effect of bundling ${ }^{16}$ (of design, construction, and operation), which is normally a hallmark of the PPPs under the existing approach at least in terms of infrastructure quality can apply to RAB as well. The caveat to this argument is, that it is valid only as long the regulator does not set the capex efficiency (savings) target too low, in which case the regulated company would invest insufficiently in the infrastructure and substitute the meeting of current regulatory capex targets (avoiding the penalties) for lack of operational efficiency in the future. In line with the example above on the estimation of WACC, one can assume that the regulators, when faced with incomplete information choose to err on the upside also in this case.

\section{Investment scope - the "capex bias"}

One of the major related concerns, with regard the volume and allocation of investment in a regulated infrastructure company, concerning both the "how" and the "what" questions is the potential "capex bias". The capex bias implies, that the regulatory company prefers a capex solution to an opex one ${ }^{17}$, as the regulated company financially gains more from pursuing capex solutions rather than opex or because the opex regulation (benchmarking) regime is perceived as "tougher" than the capex regulation regime. Arguably, this problem has been reported to exist or be perceived by the stakeholders in the regulatory process (according to OfWatt (2011) also the regulated companies themselves), but there is no empirical evidence to support the claim. The concept is similar to the commonly known Averch-Johnson-Welisz (AJW), which suggested an incentive to invest excessively in the capital assets as well. Its primary proposition states, that if a regulated firm is required to choose an output price to earn no more than an allowed rate of return, based on the level of installed capital, the firm will choose a capital-labour ratio which is higher at a given output level, than it would have been the case without regulation (Law 2014).

If the regulatory allowed rate of return is greater than the company's true cost of capital, then the firm will substitute capital for the other factor of production. One part of the question in the argument was thus, what is the "true" cost of capital of the regulated firm (which is not unrelated to our debate above and erring on the up side). The other part is on what rate base, this return is applied to, which is similar to the capex bias. Recently, a review of empirical literature on the AJW effect (Law 2014) found, that there is no or very little evidence that the effect actually existed. The possible existence of a capex bias, has prompted regulators to adjust regulation framework [i.e. TOTEX regulation, where the CAPEX and OPEX are targeted as single category and other measures; OfWat $(2011,46)$ analyses 12 options], but it is not clear, whether the incentive of capex bias can be fully removed.

\section{The higher gearing bias and inadequate returns}

The economist, Dieter Helm $(2008,2009)$ pointed out, that a single weighted average cost of capital (WACC) potentially overcompensates investors for the risks associated with the (RAB). Due to the way it was applied in regulation, it also created room for arbitrage. In the past this enabled the owners of the infrastructure companies, to extract value from the companies, by increasing the gearing of the

15 A potential caveat to this finding is that the interest of current investors might also be of short duration, while the buyers of their stake might have difficulty assessing the quality of past investments and their influence on future operating cost.

A theoretical treatise of bundling in PPPs is provided by Iossa and Martimort (2012).

17 For example, investing in a campaign to raise the awareness of consumers with regard to water pollution instead of building a new water treatment plant. The former would be recorded as operating expenditure and the later as capital expenditure. 
company through financial engineering. The actual returns were thus (for a time) over and above the "allowed" revenue. This was not an unsurmountable regulatory problem; however, its current status is outside of the scope of this paper.

More importantly a single WACC potentially undercompensate investors for major new capital projects, and potentially disincentivises capital expenditure. Helm's proposed solution was the split cost of capital, which recognises that different components of investment may have materially different risks. Separate returns for the RAB and major new capital projects could lead to a more efficient allocation of risks among investors, customers, and tax payers. The concept is not without challenge (QCA 2014; Cooper 2012; NERA 2013), but some regulators are investigating, whether it is possible to make use of the concept in more accurately determining the single WACC (which represents the mix of the risks, related to existing $\mathrm{RAB}$ and new infrastructure projects).

It can be noted that it is not immediately clear what net outcome in terms of incentives for too high or too low capex expenditure could be expected, nor is there any empirical evidence available with regard to that.

\section{Infrastructure operation - the $\mathrm{RAB}$ model in an incentive regulation framework}

The process of efficiency incentives in the case of operational expenditures is similar to efficiency incentives for capex expenditures (setting of targets, and penalties or rewards for meeting them) but more straightforward.

In the UK and elsewhere, the RAB is embedded in an RPI-X price cap regulation. The "X" reflects a measure of inefficiency, which the regulator determines and applies on the annual allowed price growth (RPI). The inefficiency adjustment is reset in regular price review periods, which typically last five years or more (e.g. eight years in the new RIIO model of OfGem, which will focus on output regulation rather than price cap regulation). This adjustment for inefficiency also introduces risk, that the regulated company will not be able to recover the full amount of the above stated costs, if it does not perform its function efficiently.

The determination of the $\mathrm{x}$-factor for OPEX is in principle subject to the same caveat as incentivising the efficiency of CAPEX (i.e. a safety margin in setting targets). But the information asymmetry challenges in this case are potentially smaller, and the consequences of inadequate incentives are more immediate and obvious, than in the case of CAPEX.

There is also more research available on the outcomes in terms of operating efficiency regulation, which is intertwined with the subject of privatisation.

With regard to ownership, there is a substantial volume of literature available on the effects or privatisation, which focuses predominantly on utilities (electricity distribution, water supply and sanitation), and less on transport. Gassner et al. (2009) provide a literature review for industrialized and developing countries, which show increases in efficiency, work reduction and other measures of better performance. Under what circumstances these improvements translate into better social welfare outcomes is potentially considered to be a question not fully resolved, but the question refers to developing and post-transition economies (Estache and Rossi 2002; Andres et al 2006). The question of better social welfare outcomes, however, may be critically related to a proper regulatory regime in place. More recent studies, such as that of Estache and Rossi (2010) explored a representative sample of 220 electric utilities from 51 development and transition countries showed that the establishment of 
a regulatory agency did contribute to the increases of efficiency (also in terms of social welfare outcomes) and was robust to the effects of firm ownership. In addition the performance of private regulated companies was superior to the performance of state owned regulated companies.

In the specific context of the RAB in an incentive based regulation framework, Parker (2004) notes that regulation and privatization in the UK, led to increased efficiency and reduced customer prices as shown in the table below, with two controversial exceptions ${ }^{18}$.

\section{Table 1. Decrease in employment in certain Great Britain network industries,} as a result of privatization and the change in retail prices

\begin{tabular}{|c|c|c|c|}
\hline Industry & $\begin{array}{l}\text { Number of employees } \\
\text { AT privatization/(year) }\end{array}$ & $\begin{array}{c}\text { Number of employees } \\
\text { AFTER } \\
\text { privatization/(year) }\end{array}$ & $\begin{array}{l}\text { Changes }\left(\text { real }^{1}\right) \text { in end } \\
\text { user prices (time of } \\
\text { study) }\end{array}$ \\
\hline $\begin{array}{l}\text { Electric power } \\
\text { distribution }\end{array}$ & $127.300(1990 / 1991)$ & $66.000(1996 / 1997)$ & $\begin{array}{r}\text { from }-25 \text { to }-34 \%(1990- \\
1999)^{2}\end{array}$ \\
\hline $\begin{array}{l}\text { Telecommunications } \\
\text { (British Telecom) }\end{array}$ & $238.000(1979 / 1980)$ & 124.700 (1999) & $\begin{array}{r}-48 \% \\
(1984-1999)^{3}\end{array}$ \\
\hline Gas distribution & $92.000(1986)$ & $70.000(1994)$ & $\begin{array}{r}-26 \% \\
(1986-1997)^{4}\end{array}$ \\
\hline \multicolumn{4}{|c|}{$\begin{array}{l}\text { Notes: (1) The figure is based on the general price level growth, which means that the nominal drop was } \\
\text { even greater. } \\
\text { (2) Measured in England and Wales. } \\
\text { (3) In this case the decrease can also be attributed to technological progress and, indirectly, an } \\
\text { (4) Increase in competition as a result of privatization. }\end{array}$} \\
\hline
\end{tabular}

Source: Parker, 2004.

The point of the above paragraphs is not to contribute to the debate on the meaning of ownership in network industries, but rather to provide a brief overview of the main direction of findings. In summary, the evidence in the case of privatized regulated network industries is not as clear cut as in the case of competitive markets and the overview of studies in Meginson and Netter (2001). But. But the studies that are available suggest that privatization on a platform of regulation can have superior social welfare outcomes when compared to state-owned enterprises.

In the water sector the regulatory system was considered lax until 1999. After that year many regulatory changes took place that led to a significant increase in the efficiency of water supply companies (Erbetta \& Cave 2007). Certain water supply firms faced financial exhaustion (also caused by inappropriate regulation) (Helm 2008). In the railway sector the results are also unclear. A study of a railway infrastructure manager Railtrack painted a mostly positive picture of the system's efficiency (Pollitt \& Smith 2002) up until the period between 1999 and 2001, when three railway accidents happened. Later research (Evans 2007) seemed to show that, statistically, the safety standards did not decrease as a result of privatization. However, in the practical reality there was no RAB, an insufficient overview over the condition of the assets, and an inadequate management in Railtrack, which prompted the railway regulator to write an almost a thousand page report on deficiencies with obligatory recommendations, just before the accidents. The government in power called for a disproportionate tightening of security measures, imposing huge financial burdens on the company which later led to its bankruptcy and again to a de facto state ownership. 


\section{Contract renegotiations and $\mathrm{RAB}$}

A challenge, that is normally not present in the traditional model, is the flexibility of the contractual framework to potential changes, which would require contract renegotiations. Economists have not yet reached a consensus on the meaning renegotiations and the related literature can be mainly associated to two main positions. In one, the renegotiations have a negative connotation as a tool, which reduces the ex-ante efficiency gains from the bidding process. Guasch (2004) reports that the majority of PPP contracts in developing nations (managed by the WB) have been renegotiated within two years of the contract signature, predominantly to the benefit of the private partner. Conversely, opportunistic behaviour by the public party is also possible, which induces the risk of expropriation and increases the cost (due to the risk premium for expropriation) for future projects. In the other position, renegotiations are considered as an inevitable response to a changing environment and incomplete contracts (Saussier, 2014), as it is impossible to foresee every eventuality over the next 20 years.

The RAB model in the framework of price cap regulation essentially represents a regulatory contract in the form of a licence -- with a string of renegotiations (price reviews). These allow adjustments to the changing environment without weakening the ex-ante commitment of the bidders or influencing the future expectations of investors.

In terms of infrastructure the regulated utilities in the UK also incur one of the lowest costs of financing, right after the government bond ${ }^{19}$.The low cost of financing effectively implies that renegotiations of the regulatory contract are possible without immediately obvious adverse effects (such as the ex-post higher cost of finance, which would signal some kind of expropriation).

A former chairman of the UK rail regulator ORR, Chris Bolt (Bolt 2007, 19) argued that in terms of practical legal execution, a licence allows for greater possibilities for modification than a contract. In practice there is a possibility for the regulator to refer a case to the Competition Commission, if changes (to the licence) cannot be agreed. In principle both organisations are independent from the government. An essential part of the apparent adequacy of the process is that it is clearly defined what is repaid and what is put at risk.

19 To suggest a sense of magnitude, we provide an illustrative comparison of the mark-up on the risk free rate for a regulated utility, which would have a rating of $\mathrm{A}$ (as is common in the UK) and PPPs, which according to Moody's (2014) achieve single A rating only 10 years after financial close. PPPs are typically structured to achieve BB+ or BBB- (EIB 2012) or BBB according to (Yescombe 2014), using Standard \& Poor's rating scale. According to Damodaran (www.stern.nyu.edu/ adamodar/pc/ratings.xls; accessed 7 May 2014), an A rating in the synthetic rate estimation the spread above the risk free rate or a 10 year government bond is $1.00 \%$. In comparison, a $\mathrm{BB}+$ rating would yield $2.75 \%$ and a $\mathrm{BBB}$ rating $1.75 \%$. 


\section{The PPP Model in Infrastructure Delivery}

In a commonly-used definition by practitioners, project finance is the financing of long-term infrastructure, industrial projects and public services based upon a non-recourse or limited recourse financial structure where project debt and equity used to finance the project are paid back from the cash flow generated by the project. In a public infrastructure context, the approach is also termed PPP or PFI in the UK, although the former term has a broader meaning ${ }^{20}$.

The essential feature of the PPP is the creation of a project company - a Special Purpose Entity (SPE). The SPE enters a long-term contract with the procuring entity to deliver and operate the infrastructure $^{21}$. The project company is almost exclusively financed with debt, with equity of the shareholders representing a minor part (commonly around 10\%).

The shareholders may include financial investors and also firms involved in project delivery and operation.

In line with Blanc-Brude and Makovšek (2013) several general features distinguish PPPs from traditional infrastructure procurement:

- The public-private agreement defines an output specification i.e. what the project is meant to achieve, as opposed to what the project is (the input).

- There is a bundling of all procurement phases from design to operations in one long-term contract (e.g. the Design Build Finance Maintain Operate contract).

- The lenders require the application of fixed-price and date-certain turnkey construction contract.

- In the context of revenues, PPPs create a commitment to pay a pre-agreed income to the SPE on the part of the public sector, provided the required service delivery and quality criteria are met. Alternatively the public sector can commit by granting the SPE the right to collect revenues from the use of infrastructure ${ }^{22}$.

20

In its broader meaning term covers a wide range of other arrangements, including management infrastructure concessions. The context of the term in our paper is limited to infrastructure project delivery and subsequent infrastructure operation.

Of interest to us is the variant, where the full scope of infrastructure delivery and related services of operation is entrusted to the private parties. This is also the case, where any efficiency incentives due to bundling of project phases would be strongest. .

In terms of risk allocation, the former variant is similar to a RAB model, because the revenues of SPE are at risk mainly from its operational performance. 
The figure below provides an example of a project finance model. In the example, which is common in practice, the developer is a parent company, which is at the same time the equity investor in the SPE and an owner of the construction company. The project finance approach normally involves the application of a turnkey contract, supported by lender comfort measures (guarantees) from the construction company, which put it at risk, in case the project is not delivered on budget and time. Alternatively, in cases, where the construction companies are financially unable to accept the construction risk, the construction budget of the SPE includes a sizeable contingency.

\section{Figure 3. An example of a PPP model in the context of infrastructure delivery and operation}

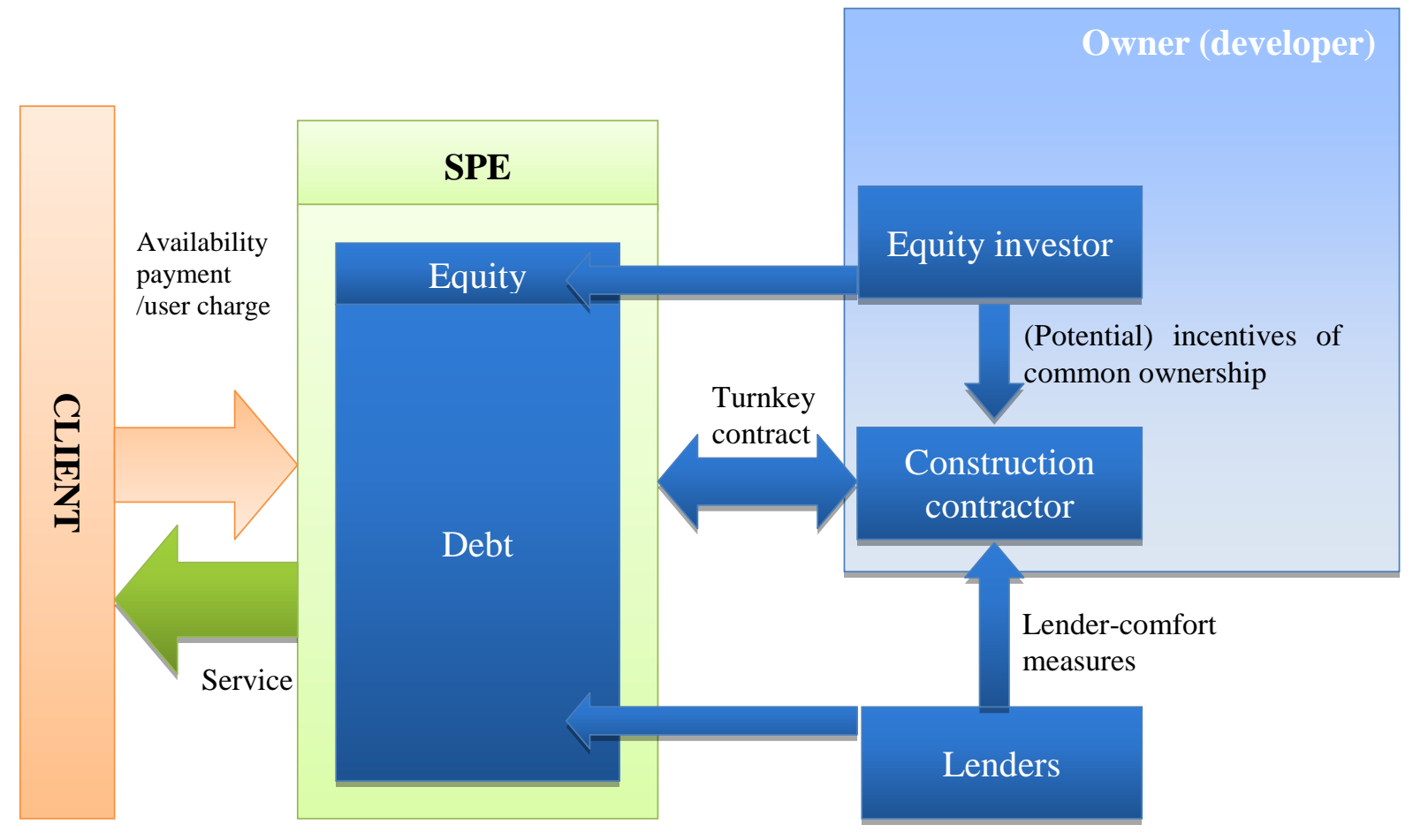

Source: Author.

\section{Infrastructure delivery - the PPP model}

As opposed to the traditional model of infrastructure delivery, the PPP model in the delivery phase has the following characteristics:

- The construction phase normally relies on the fixed price/fixed date model:

- The public sector transfers the majority of the risks to the SPE.

- Changes to the scope the scope of the project during construction involve substantial transaction cost (due to a complicated contractual setup). More importantly, the public sector might be at a disadvantage, because it is not possible to get an alternative competitive bid for the proposed changes after the construction has already started. 
- The transfer of risk decreases the number of potential bidders, who are able to absorb/manage the risk of a large scale infrastructure project - only those firms who can manage the risk well, will bid (Blanc-Brude 2013). In addition, there is also some suggestion of self-selection (people like to work with partners they already know) (Istemi et al. 2011). There is also evidence from the road sector (Blanc-Brude et al. 2009; Makovsek 2013), that in terms of ex-ante construction cost, the PPP model is substantially more expensive, even when the expected risk of cost overruns is taken into account. Indeed, Zitron (2006) in his study of 86 PPPs from the UK reported, than on average there were three bidders for each contract, and in a quarter of his sample, there were less than three bidders. Nevertheless, in a maturing international market the potential importance of these issues may be reduced overtime.

- The planning, building, and the operation phases are bundled. Furthermore, the contractual relationship between the public sector and the SPE in a mature environment shields the latter from government short-termism.

- In light of the two points above, the SPE has every incentive to pursue life-cycle cost optimization in terms of infrastructure quality, but also cost. The latter is the result of the fact, that in contrast with the RAB, the SPE is not remunerated for the construction cost directly, but through the price that was bid for the service In addition, the second most common cause for cost overruns are errors and omissions in the design documentation (Makovšek 2013, provides a literature overview for the road sector), and there is evidence, that the cost performance of the Design \& Build contract, where the two phases are bundled displays superior performance in terms of on budget delivery, when compared to DBB contracts (Ellis et al. 2007). Thus the bundling introduces additional efficiencies.

A hallmark feature of PPPs is the on budget/on time performance, which significantly supersedes the traditional procurement model options. This has been suggested by various studies, performed mainly in Great Britain (NAO 2003; NAO 2009) and Australia (Allen Consulting Group et al. 2007), which report a percentage of projects with on time delivery and are not directly comparable with studies, which deal with traditional cost performance. Only one study of the above also reports an average performance of on budget delivery (Duffield et al. 2008) - 7.8\% measured against the decision to build estimate and $4.3 \%$ measured against the contractual commitment estimate). More recently Blanc-Brude \& Makovšek (2013) analysed a sample of 75 major infrastructure projects from mainly network industries. They showed that the fixed-price contract in a PPP setup is effective, with a complete transfer of risk from the SPE to the construction contractor.

While the efficiency of the delivery process in project finance is not disputed, the price to pay for this efficiency is not well understood. This is addressed in the next two subsections.

\section{Potential for optimisation and redundancy in the delivery model}

Blanc-Brude \& Makovšek (2013) find that the SPE's are completely insulated from construction risk, which is transferred to the contractors. Moreover the fixed-price/fixed-date contract of the SPE with the construction contractor is subject to multiple incentives, which can be overlapping in nature:

- Lenders require multiple insurance levels against construction risk, which can involve multiple lender comfort measures (liquidated damages for delay and performance; a full completion guarantee; retainage and others); 
- The construction contractor can be a part of the same group company as the equity investor in the SPE.

Non-performance of the construction contractor means that it would risk the materialization of any of the lender comfort measures. In addition, the for the group company, the opportunity cost is greater than the value of the invested equity alone, because the equity share can be sold with a premium, after the construction phase of the project is completed. So the non-performance of the construction contractor could also affect the outcomes for the equity investor. Because the two could be organized as separate profit centres within the same group, it is not clear, whether any additional incentives to perform from this relationship actually arise. Further research would be needed on the contractual relations and their enforceability to better understand, whether the incentive structure and transaction cost could be streamlined.

\section{Ex-ante risk, ex-post risk and returns in a PPP}

As noted in the introduction, the PPP derives its efficiency in construction and operations through the competition for the contract. The bidders essentially compete with the pricing of the risks, to be accepted through the contract. To the extent, that they do not have perfect information on what is involved in the construction of the project or what will happen in the next 20 or more years of its operation, their bids will include a risk (aversion) premium, and the competition is supposed to reduce it to an efficient level.

Some recent research suggests this is not necessarily the case.

In terms of construction risk in the road sector Blanc-Brude et al. (2006), found on a large sample of 227 traditional and PPP procured road projects, that the ex-ante construction cost of PPPs in the EU are substantially above the cost of projects in traditional procurement. Makovsek (2013) showed that the costs are actually also substantially above the expected cost overruns in traditional procurement for road projects. Given the available data an illustration of a $19 \%$ premium was provided. Daito and Gifford (2014) show, that the same cost premium in the US road projects is $64 \% .^{23}$

PPP theory would suggest, that this is to be expected, as unlike in traditional procurement the PPP partner would invest into higher quality infrastructure, to reduce later cost of maintenance and so optimise the lifecycle cost of the project. It would not explain why the premium in the US would be so much greater (given that the nature of road construction cannot be substantially different on the two continents). Moreover, there is little evidence to support, that PPP companies actually do consider investing into more expensive infrastructure to optimize life cycle costing. NAO (2007), albeit in the case of hospitals found, that this is not the case, i.e. the PPP hospitals were not built to a higher standard of quality than traditionally procured hospitals.

Potentially in relation to this point, are the ex-post returns to PPPs. A National Audit Office report (2012) showed that expected blended equity IRRs ${ }^{24}$ are substantially above those agreed at financial

23 This point is usually ignored in Value for Money assessments, when comparing the cost of the public and the private alternative.

$24 \quad$ The equity stakes plus the subordinated portion of debt in the SPE end up in each sponsor's balance sheet. The remuneration for these investments is represented by the blended IRR of the SPE. Since sponsors must assess whether or not the project will increase the wealth of their shareholders, they will compare the blended equity IRR with their respective WACC (in simplified terms, WACC is an opportunity cost for an investor for a given type of project/industry). If this difference is positive, the 
close in two-thirds of the 118 PFI contracts, which were included in NAO's survey. Vecchi et al. (2013) showed a similar finding for the PFI hospitals in the UK. There on average the blended equity IRR was $9.27 \%$ (with $\min 4.47 \%$ and max $17.43 \%$ ) above average financing cost for these kinds of projects (WACC) . They suggest that the main reasons for the higher ex-post IRR is the use of cover rates $^{25}$ and lack of competition in the bidding phase. Thus, it is not fully clear, whether this additional cost is reflective of additional risk, but at least as regards the construction phase, this does not appear to be the case, as established by the study of Blanc-Brude \& Makovšek (2013) above, where the construction risk is fully transferred.

Apart from the premium in the basic cost of construction (for the transfer of construction risk from the SPE to the construction company), a risk premium will also included for the operational phase of the project, given that PPPs involve the delivery of complex infrastructure and require some foresight on the risks over a long period of several decades. It is an open question, whether competition against such circumstances and imperfect information could actually yield adequate results - reduce the risk premium to an efficient level.

The point above is also relevant to the idea, that PPP should be more efficient than the public side in relation to the "what" question in terms of investment, i.e. the ability to detect "white elephant" projects or other forms of wasteful public spending. If this were the case, this detection mechanism would come at a substantial $\operatorname{cost}^{26}$.

\section{Infrastructure operation - the PPP model}

The PPP model is set to capture its performance improvements when compared to the traditional model, through competition between bids, before the start of the project. In advanced contractual arrangements of PPPs in the UK (termed PFI -- Private Finance Initiative), a special procedure ${ }^{27}$ for the competitive provision of non-core services (e.g. cleaning, catering services...) can be in place. These procedures refer mainly to services, which can be expressed in simple terms. Core services, such as the infrastructure maintenance in network industries, are more complex and cannot be simply "market tested". For the regulated companies, economic regulators apply engineering studies and benchmarking with local or foreign companies in the sector to get an idea of the so called efficiency frontier and the distance of the regulated company from it. A sophisticated institution (the regulator) is required to collect the relevant data, analyse it, and apply the proper regulatory policies and incentives to the regulated company.

project is economically attractive for each of the sponsors (Vecchi et al 2013, 248), with the expected earnings above average.

Cover rates refer to internal corporate hurdle rates, which are higher that those that would be derived from capital benchmarks and are reflective of the company's (manager's) risk aversion and investment policy.

Although it can be argued, that the private sector is better at managing risks, there is no clear indication, that the private sector would actually have better information on the magnitude of risk in the first place. In terms of traffic demand risk Button \& Chen (2014) for example in a literature review show, that the private sector is no better than the public sector in forecasting traffic.

PFI contracts include provisions (NAO 2007) for a value testing (re-tendering) procedure, first occurring normally between the five and seven years into operation. It gives both the public and private sectors the opportunity to renegotiate the prices of services tested in line with market rates during the operations phase of the contract. 
For PPPs in general the core services are locked-in with the contractual arrangement that was sealed, when the winning bidder was selected.

It would likely not be efficient to establish an institution (an economic regulator) for each and every PPP (or for a portfolio of PPPs). Alternatively, if one regulator would be responsible for numerous individual infrastructure projects a substantial transaction cost would be present due to the atomization of infrastructure delivery and management. These costs are internalized and reduced, when a single large infrastructure manager is the subject of economic regulation.

There is no research available, which would reveal the comparative operational performance of PPP infrastructure projects, against a privatized regulated network industry operator or a state owned operator. But because the private partner is profit driven, it is reasonable to assume, that these projects are operationally efficient. The relevant question, however, is, if this increased efficiency is passed to the users to a sufficient extent - are superior social-welfare outcomes achieved. This question is also at the heart of the Value for Money discussion, which will be unresolved until a sufficient number of PPP projects runs their course and an ex-post analysis of their life-cycle cost (and benefits) will be possible. A comparative weakness of the PPPs, when compared to the RAB approach is thus the lack of tools to for the public sector to share the outcomes potential efficiency incentives during the operational phase of the project. This question is not unrelated to the subject of renegotiations and we address this issue briefly below.

\section{Contract renegotiations and the PPP model}

Long-term contracts are by their nature incomplete. To minimize the potential consequences of unexpected events or behaviour of contractual parties, public authorities prefer drafting overly detailed contracts to try to manage every eventuality. PPPs were also criticized by the UK as being too rigid (House of Commons 2012). Nevertheless, NAO (2008) reports that the PPP contracts in the UK are moderately flexible (renegotiations have been executed) and more recently modest savings were achieved by the public partner in PPP contracts (NAO 2013). It should be noted however, that these savings are normally not the result of changes in core services and do not resolve the challenge described in the paragraphs above. In addition, especially in terms of renegotiations, it is still unclear, whether this form of contract adjustment as opposed to the RAB will be perceived by the investors as risk. Renegotiations of a PPP contract are invariably less structured than in a RAB model, primarily, because there is no economic regulator in the background. A recent review of the causes and incidence of renegotiations around the world (Makovšek et al. 2015) found, that renegotiations are not infrequent and not limited to countries with weaker institutional structures. Predominantly, they result from the strategic behaviour of the public or the private contractual partner or both. A number of measures are considered and put in place by countries to address renegotiations with causes ${ }^{28}$, which adversely affect the economic purpose of the PPP. Some of them basically involve the distancing of the PPP contract management from the government and the introduction of an independent PPP regulator, which could deal with contract renegotiations in a transparent and systematic manner - a solution, which is already in place in the RAB model.

The possibility of renegotiations affects the cost of financing as well, depending on the ex-ante bargaining power of the investors, and the derived expectation that the contract will be upheld,

28 The cited paper goes into greater detail, when PPP renegotiations are desirable and when not. In principle renegotiations, which lead to strategic behaviour by either contractual party and lead to the defeat of the economic purpose of the model (achieving economic efficiency through competition for the contract), are not desirable. 
renegotiated to their benefit or loss. In the UK, where the contract renegotiations are generally not seen as a problem (ibid.), the financing cost of the PPP is still substantially above the cost of the government debt and the RAB model. Although estimates vary, depending on the point in history and the market situation, an estimate $8.5 \%$ was illustratively suggested, when the government cost of borrowing in the UK was 4\% at the turnout of the economic crisis in 2011 (House of Commons, 2011, 16). Earlier, pre-crisis estimates spoke of an additional cost of financing $2.4 \%$ (PWC \& Franks, 2002).

We note that the illustration would be valid for the UK PFI model, which does not involve demand based risk, whereas in cases where also the demand risk was included the cost would be substantially higher.

\section{Discussion}

The RAB and the PPP models both employ a contractual structure, which helps resolve the timeinconsistency problem with regard to infrastructure investment. A potential weakness of the RAB based approach is the difficulty in establishing proper benchmarks and incentives for an efficient delivery of infrastructure. There is also a need for an economic regulator. The challenge of the PPP model is, that it faces fewer incentives to deliver efficient social welfare outcomes and is potentially less flexible (without adverse effects) during the operational phase. In addition PPPs are characterized by a much higher cost of finance, when compared to RAB.

Overall the basic concern with regard to $\mathrm{RAB}$ in our analysis is that the approach might lead to excessive capital expenditures, thus slowly increasing the base on which the return is being calculated. Conversely, in the case of the PPP, given the complexity of the projects and the long-period of contractual commitment and uncertainty, it is questionable whether competition could lead to efficient outcomes. Put differently, in the case of the PPP, the basic concern is the required returns, and not the base.

Currently available evidence seems to suggest that the concern relating to the PPP returns and capex risk premiums by the construction companies are of a much greater magnitude than the perceived capex bias in the case of the RAB model. It is important to note, that the capex premium in a PPP arises due to risk aversion and transfer of construction risk through fixed price/date contracts. If a regulated company had used the same contracting approach, the same capex premium would be incurred.

Given the approach in our analysis ${ }^{29}$, the capex bias in the RAB model could only manifest in the regulated company, trying to construct assets to a quality standard, above the requirements of lifecycle costing optimisation or with cost overruns.

29 As defined in the chapter 2 Methodological Approach, we are only considering the "how" question in terms of infrastructure investment. Because major infrastructure would require a broader social consensus it would not be in the autonomy of the regulated company to determine, what major projects it would pursue, i.e. the »what « question is determined by the state. 
The additional challenges of the PPPs are the lack of additional operational efficiency incentives during their long lives and a lack of a contractual flexibility mechanism, which the RAB has, through the function of the economic regulator.

In general, although it is clear in terms of efficiency that both approaches can outperform the traditional model (primarily through the reduction of excess employment), there is no research available, which would compare the performance of the RAB model vs. the PPP.

In more detail, the main findings of the overview of concepts and empirical literature are summarized below.

Table 1. Illustrative summary of characteristics of two infrastructure delivery and operation models - the RAB and the PPP model

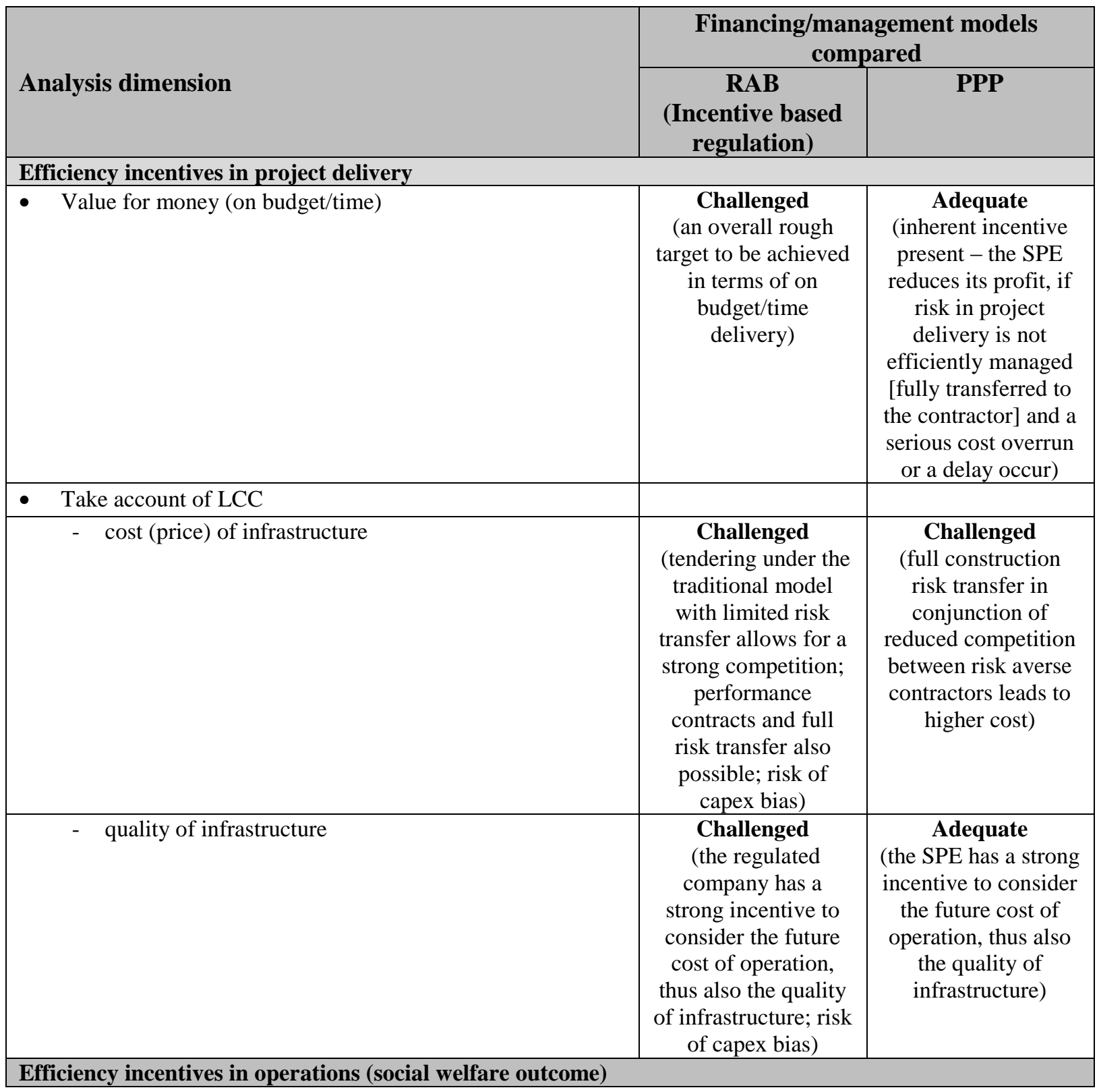




\begin{tabular}{|c|c|c|}
\hline - $\quad$ Efficiency incentives in operations & $\begin{array}{l}\text { Adequate } \\
\text { (through detailed } \\
\text { monitoring and the } \\
\text { periodic price cap } \\
\text { reviews the regulator } \\
\text { continuously exerts } \\
\text { an efficiency } \\
\text { incentive on the } \\
\text { regulated company) }\end{array}$ & $\begin{array}{c}\text { Challenged } \\
\text { (the absence of the } \\
\text { economic regulator } \\
\text { means that the social } \\
\text { welfare outcomes are } \\
\text { determined ex-ante, } \\
\text { which, over the long } \\
\text { run, implies some } \\
\text { inefficiency) }\end{array}$ \\
\hline $\begin{array}{l}\text { - Flexibility (adjustment to changes in service } \\
\text { provision/environment) }\end{array}$ & $\begin{array}{c}\text { Adequate } \\
\text { (the periodic price } \\
\text { reviews present a } \\
\text { string of contract } \\
\text { renegotiations within } \\
\text { a clearly defined } \\
\text { framework; a } \\
\text { regulator also exists, } \\
\text { which exerts } \\
\text { substantial effort in } \\
\text { monitoring) } \\
\end{array}$ & $\begin{array}{l}\text { Challenged } \\
\text { (contract } \\
\text { renegotiations do not } \\
\text { occur within a } \\
\text { clearly defined } \\
\text { framework; a } \\
\text { comparable effort in } \\
\text { monitoring to an } \\
\text { economic regulator } \\
\text { is not present) }\end{array}$ \\
\hline Cost of finance & Low & (Comparably) high \\
\hline
\end{tabular}

Source: Author.

The overview adds the cost of finance category in the end, which was not addressed in detail, but it is generally accepted, that there is a differential between the two approaches in the cost of finance. The intermediate reason for the comparably higher cost of finance in the case of PPPs is its comparably low investment rating, i.e. typically BBB- (EIB 2012) or BBB/Baa ${ }^{30}$ (Yescombe 2014), which is the bottom end of the investment grade. There are several initiatives to improve the investment rating of the PPPs, or to otherwise inform the investment community on the investment performance or risks, involved in the PPPs ${ }^{31}$.

To the extent, that the initiatives might involve the state taking back some of the risk or providing more accurate information on the performance of these investments, to improve the investment rating of PPPs, they do not address the inherent challenges of the approach as summarized above.

Other ideas have been discussed on how expand the application of the RAB principles in the financing of infrastructure or how to combine potential advantages of the RAB and the PPP model.

Dieter Helm (2009, 2010, House of Commons, 2011), for example, discussed the idea of RAB finance, where the SPE would build the project, i.e. the construction phase would be delivered as a PPP. When the project would be complete the regulator would decide, what part of the cost is "efficient" and accept the asset into the RAB, which would enable the refinancing of the construction phase loan with the (much lower) required return on the RAB. One way help start the construction and

30 To illustrate, according to Damodaran (www.stern.nyu.edu/ adamodar/pc/ratings.xls; accessed 7 May 2014), for an BBB rating in the synthetic rate estimation the spread above the risk free rate or a 10 year government bond is $1.75 \%$ and $2.75 \%$ for BBB-.

31 For example Europe 2020 Project bond initiative, the LTI project of the OECD, the research of EDHEC Risk institute, which focuses on documenting the investment characteristics of long-term investment in infrastructure. 
execute the refinancing would be through the establishment of a national infrastructure bank ${ }^{32}$, which would channel the funds from institutional investors. This logic could actually be extend to a range of projects or a network, which would allow cross subsidization across projects, and regulation during their operation, but that is actually rephrasing what the RAB model already is. A (regulated) company is a multitude of projects, running simultaneously, cross-subsidizing each other and diversifying risk internally.

These suggestions, however, primarily focus on the RAB as a vehicle, which ensures low cost of financing, and do not go into greater detail with regard to incentives in both approaches. A slightly adjusted approach, which would better fit the aims in the table 1 above is discussed below, which may have been already also considered in practice. With a relatively straightforward adjustment, it would be possible to introduce the efficiency of infrastructure delivery from PPP into the regulated RAB, without losing the efficiency incentives during operation.

\section{Project RAB finance}

We have noted in previous chapters that in the infrastructure delivery phase within a PPP framework one of the key determinants of good delivery performance is, that the construction risk is fully transferred via the fixed price/fixed date contract:

- There are multiple lender protection measures overlapping with ownership (money at risk) incentives;

- The due diligence of lenders, which demanded the protection measures, potentially has a beneficial effect on the quality of project delivery and management (but there is no empirical evidence to support the necessity of this aspect in light of other incentives for delivery efficiency).

Both characteristics of the two bullets above would be met, if the regulated companies themselves established an SPE for the delivery of a large new project. In that case SPE would be financed by:

- money, raised by the regulated utility through corporate finance channels (e.g. through corporate bonds) - technically the majority the capital of the SPE would then consist of equity, invested by the regulated utility;

- a smaller, but in absolute terms still a substantial part of debt from lenders could be present, which would ensure the due diligence as in the PPP;

- a small participation of the contractor in the SPE's equity, the same as it would be the case in the PPP to meet the money at risk criterion.

32 The bank's role would be to match savings (largely pension and life funds) with investments in infrastructure projects such as those currently included in the PPP (PFI) contracts. The bank would "buy" completed projects, put a RAB wrapper around them, and then sell them onto the pension and life funds. 
Once the construction phase is be finished, the regulated company would buy out other shareholders from the SPE and lenders and merge the assets into its existing RAB. The SPE would in this way become just a bubble to imitate incentives from a PPP for the delivery of infrastructure, and would be reassimilated once the infrastructure is delivered.

The efficiency outcomes of such a setup would be easier to observe for the economic regulator, since the responsibility for any potential cost overruns (apart from force majeure) could be clearly and transparently allocated (e.g. scope changes during construction would clearly be the responsibility of the regulated utility).

Figure 4. An illustration of the Project RAB finance

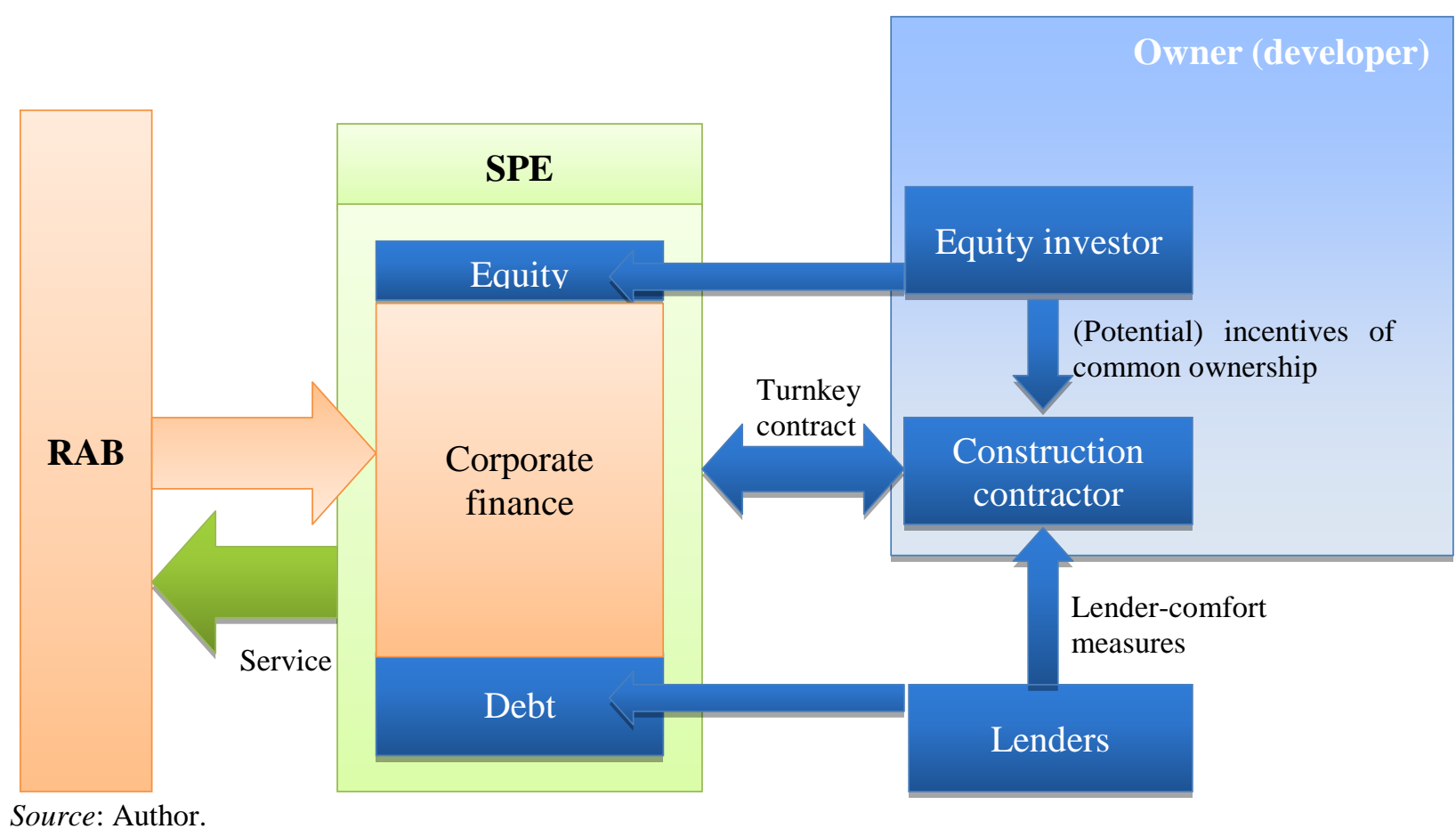

The incentives of asset life cycle optimisation would still be present and the cost of finance would be minimized, due to the corporate financing through the RAB.

The structure above assumes a replication of the incentive structure during the construction phase of the infrastructure. It is questionable, if this is actually necessary. As noted above and in our review, the incentives for the construction contractor are many and overlap. Potentially, a similar risk transfer to the construction contractor and the use of fixed price/fixed date contract, with an arrangement, where his money would be at risk (e.g. like retainage) could possibly be achieved without the SPE, with a construction performance contract only. In that way transaction cost would be further reduced 
Table 2. Illustrative summary of characteristics of the Project RAB finance model

\begin{tabular}{|c|c|}
\hline Analysis dimension & $\begin{array}{c}\text { Project RAB finance } \\
\text { (Incentive based regulation) }\end{array}$ \\
\hline \multicolumn{2}{|l|}{ Efficiency incentives in project delivery } \\
\hline - $\quad$ Value for money (on budget/time) & $\begin{array}{c}\text { Adequate } \\
\text { (inherent incentive present - if substantial } \\
\text { cost overruns and delays do occur [with a } \\
\text { fixed price contract] the regulated company } \\
\text { will incur profit loss) }\end{array}$ \\
\hline \multicolumn{2}{|l|}{ - $\quad$ Take account of LCC } \\
\hline - cost (price) of infrastructure & $\begin{array}{c}\text { Challenged } \\
\text { (construction risk transfer in conjunction of } \\
\text { reduced competition between risk averse } \\
\text { contractors leads to higher cost) }\end{array}$ \\
\hline - quality of infrastructure & $\begin{array}{l}\text { Challenged } \\
\text { (the regulated company has a strong } \\
\text { incentive to consider the future cost of } \\
\text { operation, thus also the quality of } \\
\text { infrastructure; capex bias risk still applies) }\end{array}$ \\
\hline \multicolumn{2}{|c|}{ Efficiency incentives in operations (social welfare outcome) } \\
\hline - $\quad$ Efficiency incentives in operations & $\begin{array}{c}\text { Adequate } \\
\text { (through detailed monitoring and the } \\
\text { periodic price cap reviews the regulator } \\
\text { continuously exerts an efficiency incentive } \\
\text { on the regulated company) }\end{array}$ \\
\hline $\begin{array}{l}\text { - Flexibility (adjustment to changes in service } \\
\text { provision/environment }\end{array}$ & $\begin{array}{l}\text { Adequate } \\
\text { (the periodic price reviews present a string of } \\
\text { contract renegotiations within a clearly } \\
\text { defined framework; a regulator also exists, } \\
\text { which exerts substantial effort in monitoring) }\end{array}$ \\
\hline Cost of finance & Low \\
\hline
\end{tabular}

Source: Author.

Below we address some of the limits of the proposed approach.

\section{The limits of Project RAB finance}

The solution proposed above appears to offer superior incentives, when compared to the traditional PPP. In the network industries, however, where the Project RAB finance could generally be regarded as the preferred solution (for example, in utility networks, transport networks and elsewhere), it might not be applicable to projects of all sizes and complexity. We address this question in an example below. 
To our knowledge the exact approach as proposed in this paper has not yet been applied in practice, however, a recent similar project is in development -- The Thames Tideway Tunnel ${ }^{33}$ (hereinafter TTT). The project addresses the discharges of untreated sewage into the Thames River in London, through the construction of a $25 \mathrm{~km}$ interception, storage and transfer tunnel that will transfer the sewer to a treatment plant.

\section{Figure 5. The basic logic of the TTT}

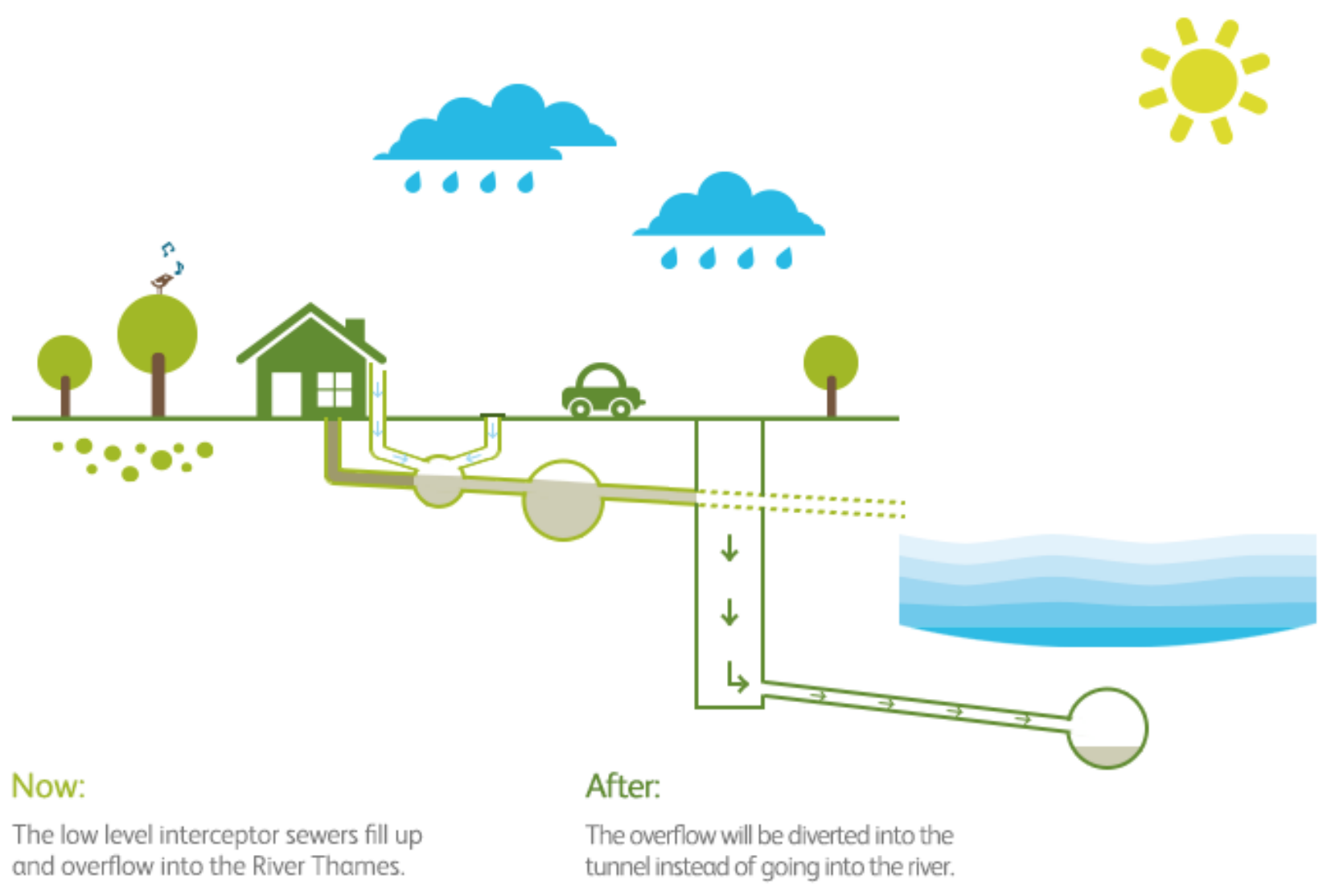

Source: TTT, 2014.

Within this project the Thames Tideway Tunnel Ltd will be a new regulated utility company that will design, construct and finance the tunnel. According to the homepage of the company (accessed 17 June 2014) "the company will have its own licence with revenues determined by the regulator Ofwat, and will collect bill payments for the tunnel via Thames Water Utilities Ltd (hereinafter TWUL; the

33

The TTT is a $£ 4.2$ billion project in London, addressing a growing problem of tens of millions of tonnes a year of sewage spills into the river. It is planned that the main construction work will start in 2016 and finish in 2023. More information about the project is available here: http://www.thamestidewaytunnel.co.uk/. 
company is the largest water and wastewater services company in the UK). Thames Water will continue to provide water and wastewater services to its customers as it does now".

We describe the project example in a few points, based on publicly available information on the project's homepage:

- The financing:

- The financing will be executed through the SPE, which will be put in a RAB model. Around $£ 1.4$ billion of the project will be funded by the TWUL (through corporate finance) and around $£ 2.8$ billion through the SPE (project finance). Given that the project was still being structured at the time of this paper, so these numbers may be different, when financial close is reached.

- The delivery:

- The TWUL, in charge of operating the sewer network, will prepare the reference design, setting out the overall outline parameters of the scheme. TWUL will conduct land acquisition, certain enabling works, certain interface works and other tasks.

- The project does not have a fixed price/date contract for the construction phase due to large construction risk - the risk will be shared/borne by the government (the traditional delivery approach) to reduce the cost of finance. Shareholders can inject additional capital to cover for the cost overruns, the economic regulator might increase the allowed return on the RAB (prices for the users), the government might cover the cost overruns or lastly, the project may be discontinued. Technically, the execution of the project will be managed by TWUL's existing project management contractor. TWUL will procure on TTT's behalf an independent technical advisor, which will verify the expenditure on the project and has a duty of care to all parties.

- Operation:

- The regulator OfWat will also design an incentive based regulation mechanism, similar to the existing one for TWUL. This would ensure the presence of incentives for operational efficiency after execution and place the assets of the SPE in a RAB. We note though that the expected cost of operation are dwarfed, compared to the capital value of the project.

We are not familiar with the details, why this solution was chosen, as opposed to the one discussed in this paper ${ }^{34}$, but in both setups the total exposure to risk in revenue cash flows (regulatory risk) and expenditure cash flows (construction and operational risk) would be the same. Because in the current TTT approach the financing is effectively executed through two entities, the same quantity of risk will be divided between the SPE and TWUL. This will have a different impact on the credit rating of both entities (the impact on the TWUL will be less severe; but stronger for the SPE), but also potentially insulate TWUL in case a massive failure in project delivery occurs. The available information on the

34 In line with the discussed solution in this paper, TWUL would raise the entire finance through RAB, where the existing asset base would be increased for the expected CAPEX value of the tunnel. All other arrangements would remain the same and the TWUL would engage with the construction contractors directly or through an SPE. The immediate benefit would be lower complexity, and no interfaces between the TWUL and TTT. 
projects home page suggests, that this solution may better meet the expectations of the regulator (in terms of the credit rating of the TWUL or other aspects) or be more prudent from a risk management perspective. But it is also more expensive:

- $\quad$ "The equity risk profile of Thames Tideway Tunnel Ltd will be similar to a business-as-usual regulated water/waste-water company in England and Wales, although there may be a premium required by the market due to the new company being the first of a kind.

- $\quad$ The debt is expected to achieve an investment grade rating and this will be a condition of its licence - which mirrors the existing licence requirements of the other water companies (ibid.)."

The example briefly highlighted above suggests, that a model, close to the one proposed, could still be applied. The case above, however, may not be the best example for our debate on project finance $\mathrm{RAB}$. The scheme is very complex, is undergoing structuring for a long time (about four years) and in terms of OPEX efficiency the incentive framework will not play a big role (the OPEX for the tunnel is minimal, compared to the CAPEX). Adjustments to the generic solution may be necessary, when projects to be delivered are large, when compared to the RAB of the regulated company ${ }^{35}$ or have large risks. Delivery schemes involving risk sharing arrangements, alliancing may come into play.

\section{Conclusion}

In this paper we have attempted to review the empirical literature of two selected models of infrastructure delivery and operation, which allow the participation of private finance -- the RAB in the framework of incentive regulation, and the PPP model. The distinctive difference of the two approaches is that one derives its efficiency through the competition with the regulator, and the other through the competition for the contract.

Our focus was on incentives and efficiency. Both approaches were compared against the traditional model of infrastructure delivery and operation.

Overall the basic concern with regard to $\mathrm{RAB}$ in our analysis is that the approach might lead to excessive capital expenditures, thus slowly inefficiently increasing the asset base on which the return is being calculated. Although, the incentives that would lead to the occurrence of this problem are there, there is no empirical evidence to suggest they have a non-marginal effect or that they are not offset by other incentives, including regulatory monitoring. Conversely, in the case of the PPP, given the complexity of the projects and the long-period of contractual commitment and uncertainty, it is questionable whether competition could lead to efficient outcomes. Put differently, in the case of the PPP, the basic concern is the required returns above and beyond actual risks, and not the asset base.

35 The CAPEX of the project discussed above is $£ 4.2$ billion, and represents a share of $36.5 \%$ of the TWUL's value of the RAB (its value for the business year as at 31 March 2014 was $£ 11.5$ billion). If we compare the project's CAPEX against current tangible assets of TWUL on the same reference date or $£ 9.9$ billion, the percentage share increases to $42 \%$. 
It is important to note the key difference between the challenges in the two concepts - the challenge in the RAB model is the information asymmetry, whereas the challenge in the PPP model is uncertainty. To illustrate, an engineering audit, where an asset management model with time series data is available, might determine, whether the effects of a capex bias are present. But an uncertainty of forecasting the future for example has its inherent limits.

Available evidence seems to suggest, that the concern relating to the PPP returns is of a much greater magnitude than the perceived capex bias in the case of the RAB model, given that the latter is not easily detectable.

Other weaknesses of the basic PPP model, when compared to the RAB involve the lack of efficiency incentive framework during the operational phase and no comparable renegotiations framework. Attempting to solve these challenges of the PPP model, would effectively bring us closer to the RAB model (i.e. establishing a regulator to manage contract renegotiations and benchmark performance over a range of PPPs).

Our findings allowed us the possibility to propose a relatively straightforward adjustment of the regulated $\mathrm{RAB}$ model to include the advantages of PPPs in infrastructure delivery, thus offsetting the weaknesses of the RAB model in the infrastructure delivery phase, while retaining the benefits in the phase of infrastructure management and the low cost of finance of the RAB model. The proposal outlined in this paper was dubbed Project RAB finance for illustrative purposes and a similar approach is already applied in the Thames Tideway Tunnel, albeit a very specific project.

Its strong point is that it is the technically preferred solution, whatever the open questions and considerations with regard to Value for Money in PPPs in network industries, such as transport (rail and road), utilities or other examples. The prerequisite is the establishment of a RAB and an incentive regulation framework with a regulator. A discussion, whether the proposed approach is equally applicable or recommendable across countries with different levels of institutional and political maturity is outside the scope of this discussion paper.

When the goal is to deliver major projects, additional constraints or goals may have to be taken into account, that require the adjustment of Project RAB finance approach (such as the inability to apply a fixed price/fixed date contract due to large construction risk).

Given that in the context of transport infrastructure in most modes assets are already there (national road, rail networks), an option may be simply to put the existing network in a RAB and use performance/risk sharing contracts to deliver new infrastructure, without project finance.

The analysis thus reveals several major challenges, compounded by the lack of empirical data, which obscure the view on potential further improvements:

1. Is it possible to replicate the infrastructure delivery performance of a PPP, without the SPE or is it at least possible to reduce the transaction cost and maintain an equally strong incentive structure in a leaner contractual setup (is a fixed price/fixed date contract, combined with operations and maintenance contract or simply a risk sharing scheme, sufficient to achieve similar efficiency improvements)?

2. In major complex projects, where the risk prevents fixed price/fixed date contracts, the comparable efficiency of different risk sharing arrangements is unclear (there is no empirical 
data/research available; e.g. how do risk sharing or alliancing schemes perform vs. other approaches)?

3. Where they can be, is it at all advisable to use fixed price/fixed date contracts for infrastructure projects (do the incentives for better management of the construction risk offset the lack of knowledge about the risk, the risk premium and the potential lack of sufficient competition)? It may well be, that the preferred solution is not to use fixed price/fixed date construction contracts for large infrastructure projects in the first place, but rather a construction performance contract with some kind of risk sharing scheme/money at risk.

Answers to questions like the ones above, would provide us with greater insight, how the preferred balance between the structure of the model, risk allocation, efficiency incentives, cost of finance, and the objectives of the regulator, is influenced by project characteristics.

Clearer understanding of these issues, may lead to better solutions, not only in the network industries such as transport, but also sectors, where projects have large capital outlays and involve large risks.

Lastly, many countries and organisations, including the international organizations like the OECD, are currently focussing on attracting alternative financial institutions, primarily pension funds and insurance companies and lower the reliance on commercial banks in infrastructure financing. The $\mathrm{RAB}$ model seems to be a naturally more attractive option to institutional investors may have a limited appetite for risk. But no matter the source of finance, better understanding of the relationships between the transfer of risk, pricing, incentives, and outcomes is crucial in informing future policies. 


\section{Bibliography}


1. Andres, L. ; Foster, V. ; Guasch, J. L. (2006). The Impact of Privatization on the Performance of the Infrastructure Sector: The Case of Electricity Distribution in Latin American Countries. Policy Research Working Paper 3936. World Bank, Washington, DC.

2. Ansar, A.; Flyvbjerg, B.; Budzier, A.; Lunn, D. (2014). Should we build more large dams? The actual costs of hydropower megaproject development. Energy Policy, http://dx.doi.org/10.1016/j.enpol.2013.10.069i

3. Blanc-Brude, F., Goldsmith, H., \& Välilä, T. (2009). A comparison of construction contract prices for traditionally procured roads and public-private partnerships. Review of Industrial Organization, 35(1-2), 19-40.

4. Blanc-Brude, F.; H. (2013). Risk transfer, self-selection and ex post efficiency in public procurement Revue d'Economie Industrielle, Volume 141, 149-180.

5. Bolt, C. (2007). Regulating by contract and licence: the relationship between regulatory form and its effectiveness. CRI - Centre for the Studies of Regulated Industries occasional lectures. University of Bath.

6. Button, K; Chen, Z. (2014). Demand forecasting errors and the ownership of infrastructure, Applied Economics Letters, 21:7, 494-496.

7. Cantarelli, C. C., van Wee, B., Molin, E. J. E., Flyvbjerg, B., (2012a). Different cost performance: different determinants? The case of cost overruns in Dutch transport infrastructure projects. Transport Policy, vol. 22, pp. 88-95.

8. Cantarelli, C. C., van Wee, B., Molin, E. J. E., Flyvbjerg, B. (2012b). Characteristics of cost overruns for Dutch transport infrastructure projects and the importance of the decision to build and project phases. Transport Policy, vol. 22, July 2012, pp. 49-56.

9. Cooper, I. (2012). Comment on the split cost of capital proposal of Professor Helm, submitted by BA. Ian Cooper, Professor of Finance, London Business School.

10. Daito, N. and J. Gifford (2014), US highway public private partnerships: Are they more expensive or efficient than the traditional model? Managerial Finance, 40(11), 1131-1151.

11. Dobbs, I.M. (2011). 'Modelling welfare loss asymmetries arising from uncertainty in the regulatory cost of finance', Journal of Regulatory Economics 39, pp.1-28.

12. Dobbs, R.; Pohl, H.; Lin, D. Y.; Mischke, J.; Garemo, N.; Hexter, J.; Matzinger, S.; Palter, R.; Nanavatty, R. (2013). Infrastructure productivity: how to save \$1 trillion a year. McKinsey Global Institute.

13. Duffield, C.; Raisbeck, P.; Xu, M. (2008). Report on the performance of PPP projects in Australia when compared with a representative sample of traditionally procured infrastructure projects, National PPP Forum - Benchmarking Study, Phase II.

14. EIB (2012). Financing PPPs with project bonds: Issues for public procuring authorities. EPEC. Luxembourg: EIB.

15. Ellis, R.; Pyeon, J.H.; Herbsman, Z.; Minchin, E.; Molenar, K. (2007). Evaluation of Alternative Contracting Techniques on FDOT Construction Projects. Tallahassee, Florida.

16. Estache, A.; Rossi, M. (2002). How Different Is the Efficiency of State and Private Water Companies in Asia? World Bank Economic Review 16 (1): 139-48.

17. Frontier Economics. (2010). Future price limits - Form of control and regulated/unregulated business: A report prepared for ofwat Frontier Economics Ltd. London.

18. Frontier Economics. (2014). Evidence in support of setting allowed rates of return above the midpoint of the WACC range -- a report prepared for Transpower New Zealand Ltd.

19. Helm, D. (2009). The Challenge of Infrastructure Investment in Britain, in: Delivering a 21st Century Infrastructure for Britain, Caldecott, B, Helm, D and Wardlaw, J, Policy Exchange, September.

20. Helm, D. (2010). Infrastructure and infrastructure finance: The role of the government and the private sector in the current world. EIB Papers, Vol. 15. No. 2. EIB. Luxemburg. 
21. Helm, D. R. (2008). A New Regulatory Model For Water: The Periodic Review, Financial Regulation and Competition, May.

22. Helm. D. (2009). Infrastructure investment, the cost of capital, and regulation: an assessment. Oxford Review of Economic Policy, Volume 25, Number 3. Oxford University Press, Oxford.

23. Hendricks, W. (1977). Regulation and Labor Earnings, Bell Journal of Economics, 8:183-96.

24. House of Commons (2011). Treasury Committee. Private Finance Initiative. Seventeenth Report of Session 2010-12. Volume I: Report, together with formal minutes. London: The Stationery Office.

25. Iossa, E.; Martimort, D. (2012). Risk allocation and the costs and benefits of public-private partnerships. The RAND Journal of Economics 43.3: 442-474.

26. Istemi, D.; Khadaroo, I.; Stapleton, P.; Stevenson, C. (2011). Risks and the financing of PPP: perspectives from the financiers. The British Accounting Review 43, no. 4: 294-310.

27. Jahren, C. T.; and Ashe, A. M. (1990). Predictors of Cost Overrun Rates. Journal of Construction Engineering and management, vol. 116(4).

28. Jenkins, C. (2011). RIIO Economics. Examining the economics underlying Ofgem s new regulatory framework. In 11th CCRP workshop, February.

29. Joskow, P. L. (2008). Incentive regulation and its application to electricity networks. Review of Network Economics, 7(4).

30. Law, S. M. (2014). Assessing the Averch-Johnson-Wellisz Effect for Regulated Utilities. International Journal of Economics and Finance, 6(8), p41.

31. Makovšek, D. (2013). Public Private Partnerships, Traditionally Financed Projects, And Their Price. Journal of Transport Economics and Policy (JTEP), vol. 47(1): pp 143-155.

32. Makovšek, D.; Hasselgren, B.; Perkins, S. (2015). Public Private Partnerships for Transport Infrastructure: Renegotiations, How to Approach them and Economic Outcomes. Discussion Paper No. 2014-25. International Transport Forum at the OECD. Paris.

33. Makovšek, D.; Tominc, P; Logožar, K. (2012). A Cost Performance Analysis of Transport Infrastructure Construction in Slovenia. Transportation. (Springer). Available online: http://www.springerlink.com/content/7403600140x007kx/

34. Moody's (2014). Default and recovery rates for project finance bank loans 1983-2012. Technical report, Moody's Investor Service, London, UK.

35. Mott MacDonald (2002). Review of large public procurement in the UK. HM Treasury. London

36. NAO. (2002). Pipes and Wires. REPORT BY THE COMPTROLLER AND AUDITOR GENERAL. HC 723 Session 2001-2002. London: The Stationery Office.

37. National Audit Office (2003). 'PFI: construction performance', Report by the Comptroller and Auditor General HC 371 Session 2002-2003. London: The Stationery Office.

38. National Audit Office (NAO). (2009). Performance of PFI construction. A review by the private finance practice. London: The Stationery Office.

39. National Audit Office (NAO). (2007). Benchmarking and Market Testing the Ongoing Service Component of PFI Projects HC 453, Report by the Comptroller and Auditor General, Session 2006-2007. London: The Stationery Office.

40. National Audit Office (NAO). (2007). Department for transport: estimating and monitoring the costs of building roads in England', Report by the Comptroller and Auditor General HC 321 Session 2006-7. London: The Stationery Office.

41. National Audit Office (NAO). (2008). Making Changes in Operational PFI Projects HC 205, Report by the Comptroller and Auditor General, Session 2007-2008. London: The Stationery Office.

42. National Audit Office (NAO). (2012). Equity investment in privately financed projects. London: The Stationery Office. Available at: www.nao.org.uk/publications 
43. National Audit Office (NAO). (2013). HM Treasury. Savings from operational PFI contracts. London: The Stationery Office.

44. National Audit Office. (2007). 'Improving the PFI tendering process'. London: The Stationery Office. Available at: www.nao.org.uk/publications.

45. NERA. (2013). Review of QCA's Discussion Paper "Risk and the Form of Regulation" Report for Aurizon. NERA Economic Consulting.

46. NERA. 2004. Enhancement framework in regulated utilities: A report for Network Rail and ORR. NERA Economic Consulting. London.

47. OfWat. (2011). Capex bias in the water and sewerage sectors -substance, perception or myth? A discussion paper. OfWat. London

48. Parker, D. (2004). The UK's Privatisation Experiment: The Passage of Time Permits a Sober Assessment. CESIFO working paper no. 1126, category 9: industrial organisation.

49. PricewaterhouseCoopers; Franks, J. (2002). Study into Rates of Return Bid on PFI Projects, The Office of Government Commerce, London: The Stationery Office.

50. QCA. (2014). Information paper: The split Cost of Capital Concept. Queensland Competition Authority. Australia: Brisbane.

51. Rose, N. L. (1987). Labor Rent Sharing and Regulation: Evidence from the Trucking Industry. Journal of Political Economy, 95: 1146-1178.

52. Rothballer, C. (2012). Infrastructure Investment Characteristics: Risk, Regulation, and Inflation Hedging, Doctoral thesis, Technical University of Munich. Available online at the German National Library: http://dnb.info/1030099901/34.

53. Salinger, M. E. 1984. Tobin's q, Unionization, and the Concentration-Profit Relationship. Rand Journal of Economics, 15:159-170.

54. Saussier, S. (2012). An Economic Analysis of the Closure of Markets and other Dysfunctions in the Awarding of Concession Contracts. European Commission. Directorate General for Internal Policies.

55. Savedoff, W.; Spiller, P. (1999). Spilled Water: Institutional Commitment in the Provision of Water Services in Latin America, Washington DC: Inter-American Development Bank.

56. Sovacool, B. K.; Gilbert, A.; \& Nugent, D. (2014). Risk, innovation, electricity infrastructure and construction cost overruns: Testing six hypotheses. Energy, 74, 906-917.

57. Stern, J. (2013). The Role Of The Regulatory Asset Base As An Instrument Of Regulatory Commitment. Centre for Competition and Regulatory Policy (CCRP). City University London. CCRP Working Paper No 22.

58. TTT (2014). Thames Tideway Tunnel. Thames Tideway Tunnel Ltd. Homepage: http://www.thamestidewaytunnel.co.uk/ (accessed 17 June 2014).

59. Vecchi, V.; Hellowell, M.; Gatti, S. (2013). Does the private sector receive an excessive return from investments in health care infrastructure projects? Evidence from the UK. Health Policy 110.2: 243-270.

60. Williams, T.P.; Miles, J.C.; Moore, C. J. (1999). Predicted cost escalations in competitively bid highway projects. Proceedings of the Institution of Civil Engineers - Transport, vol. 135(4): pp 195-199.

61. Yescombe, E. R. (2014). Principles of project finance. Academic Press.

62. Zitron, J. (2006), "Public-private Partnership Projects: Towards a Model of Contractor Bidding Decision-making”, Journal of Purchasing and Supply Management, 12, 53-62. 
